\title{
Restriction to large-scale gene flow vs. regional panmixia among cold seep Escarpia spp. (Polychaeta, Siboglinidae)
}

\author{
Dominique A. Cowart ${ }^{1,{ }^{*}}$, Chunya Huang ${ }^{1}$, Sophie Arnaud-Haond ${ }^{2}$, Susan L. Carney ${ }^{3}$, \\ Charles R. Fisher ${ }^{1}$, Stephen W. Schaeffer ${ }^{1}$
}

\author{
${ }^{1}$ Department of Biology, The Pennsylvania State University, University Park, PA, USA \\ 2 Département des Ressources physiques et Ecosystèmes de Fond de mer (REM), IFREMER (Institut Français \\ de Recherche pour l'Exploitation de la MER), Unité Environnement Profond-DEEP du, Plouzané, France \\ ${ }^{3}$ Department of Biology, Hood College, Frederick, MD, USA \\ *: Corresponding author : Dominique A. Cowart, Fax: (814) 8659131 ; email address : dac330@psu.edu
}

\begin{abstract}
:
The history of colonization and dispersal in fauna distributed among deep-sea chemosynthetic ecosystems remains enigmatic and poorly understood because of an inability to mark and track individuals. A combination of molecular, morphological and environmental data improves understanding of spatial and temporal scales at which panmixia, disruption of gene flow or even speciation may occur. Vestimentiferan tubeworms of the genus Escarpia are important components of deep -sea cold seep ecosystems, as they provide long-term habitat for many other taxa. Three species of Escarpia, Escarpia spicata [Gulf of California (GoC)], Escarpia laminata [Gulf of Mexico $(\mathrm{GoM})]$ and Escarpia southwardae (West African Cold Seeps), have been described based on morphology, but are not discriminated through the use of mitochondrial markers (cytochrome oxidase subunit 1; large ribosomal subunit rDNA, 16S; cytochrome b). Here, we also sequenced the exonprimed intron-crossing Haemoglobin subunit B2 intron and genotyped 28 microsatellites to (i) determine the level of genetic differentiation, if any, among the three geographically separated entities and (ii) identify possible population structure at the regional scale within the GoM and West Africa. Results at the global scale support the occurrence of three genetically distinct groups. At the regional scale among eight sampling sites of E. laminata $(n=129)$ and among three sampling sites of E. southwardae $(n=80)$, no population structure was detected. These findings suggest that despite the patchiness and isolation of seep habitats, connectivity is high on regional scales.
\end{abstract}

Keywords : deep sea ; hydrocarbon seep ; microsatellite ; population structure ; siboglinid ; vestimentiferan tubeworm 


\section{Introduction}

55 A multitude of factors influence speciation and distributional ranges of marine

56 populations, including larval biology, life history, adult physiology, geographic and

57 oceanic barriers, as well as temperature (Jackson 1974). In this context, life history can

58 influence connectivity in marine habitats by either preventing or promoting isolation of

59 populations (Palumbi 1992). Ocean current dynamics add another dimension to the

60 dispersal of marine groups, influencing population ranges by linking fragmented habitat

61 patches (Johnson and Black, 1984; Wares et al. 2001; Hedgecock et al. 2007). True

62 biological ranges of marine invertebrates in the deep sea can be especially difficult to

63 assess given the lack of morphological diversity and the inability to cross and rear

64 offspring (Palumbi 1994). Furthermore, physical limitations of sampling in the deep sea

65 have inhibited extensive study of deep dwelling populations. Molecular genetic tools,

66 combined with environmental and morphological data, are now universally accepted

67 approaches for elucidating evolutionary lineages in deep-sea animals (Vrijenhoek et al.

68 1994; Etter et al. 1999; Vrijenhoek 2010). Additionally, studies of biogeography, genetic

69 structure and ecological adaptation can provide information on the scales at which

70 panmixia is replaced by gene flow restriction or disruption; if these processes are active

71 over appropriate evolutionary time scales, they may lead to speciation. This question is

72 particularly germane to the deep sea where distinct biogeographic provinces support an

73 expectation of isolated populations in different regions, while the large scale dispersal

74 potential of many taxa, and some population genetic data, suggest the occurrence of

75 regular colonization events over large geographic distances, 


\section{Escarpia vestimentiferan tubeworms}

78 Hydrocarbon seeps, which are located on passive ocean margins worldwide, fuel

79 specialized deep-sea ecosystems. In the Gulf of Mexico, the continental slope has

80 developed distinctive topography over time as a result of sediment compaction of a thick

81 salt layer, and subsequent creation of diapirs and faults; it is through these faults that

82 hydrocarbon fluids and gasses migrate to the seafloor (Andersen et al. 1983; Sassen et al.

83 1994a; Cordes et al. 2009; Haas et al, 2010). The constant deformation of the salt layer

84 controls the level of seepage (Roberts and Aharon 1994) which supports specially

85 adapted chemosynthetic fauna, including the vestimentiferan tubeworms (Family:

86 Siboglinidae), a group of polychaete worms that lack digestive tracts and depend on

87 endosymbiotic bacteria for their nutrition (Childress and Fisher 1992). Seep

88 vestimentiferan larvae settle on exposed carbonate rock that is generated as a by-product

89 of bacterial hydrocarbon degradation (Sassen et al. 1993). Tubeworms extend the

90 posterior portion of their bodies ("roots") deep into the sediment to acquire the supply of

91 sulfide necessary to maintain their symbioses (Julian et al. 1999; Freytag et al. 2001).

92 These special adaptations allow individuals to have long life spans; at least two

93 tubeworm species in the Gulf of Mexico can live for centuries (Bergquist et al. 2000;

94 Cordes et al., 2007a; Fisher et al. 2007). Vestimentiferans are important components of

95 seep habitats, as they cluster in aggregations that form "bush-like" three-dimensional

96 structures (Figure 1A), which provide living space and protection for a variety of other

97 fauna (Bergquist et al. 2003). Furthermore, due to their dependence on hydrocarbons,

98 habitats suitable for tubeworm communities can be separated by hundreds of kilometers

99 (Brooks et al., 1987; Roberts et al., 2007). 
101 the temperate and tropical continental margins of the Atlantic and Pacific Oceans (Olu et 102 al. 2010). Three species have been described within the genus. Escarpia laminata (Jones

103 1985) is distributed across the Lower Louisiana Slope in the Gulf of Mexico (GoM), and

104 is found at depths from $\sim 950-3300 \mathrm{~m}$ (McMullin et al. 2003; Miglietta et al. 2010).

105 Escarpia spicata (Jones 1985) is known from the western coast of North and Central

106 America and the Gulf of California, and can inhabit seeps, hydrothermal vents and whale

107 falls below 1000m (Feldman et al. 1998; Vrijenhoek et al. 2007). Escarpia southwardae

108 (Andersen et al. 2004) occurs at pockmark depressions at West African Cold Seeps

109 (WACS) distributed along the Congo River Canyon at depths below 3000m (Ondréas et

110 al. 2005; Olu-Le Roy et al. 2007).

111 All three Escarpia have similar gross morphology (Figure 1B). Members of each

112 group have an axial rod on the top of the obturaculum, and the lack of large flare rings on

113 their tubes contrasts with a related species, Seepiophila jonesi (Gardiner et al. 2001).

114 Each described species differs in the shape of the axial rod, and E. spicata has a ventral

115 ridge that is not present in E. laminata (Jones 1985). Additionally, E. southwardae is the

116 only vestimentiferan known that does not have pinnules on the plume. Pinnules are

117 thought to be the primary site of $\mathrm{O}_{2}$ and $\mathrm{CO}_{2}$ uptake in the other species (Andersen et al.

118 2004). Although the three described Escarpia species are geographically distant and

119 morphologically distinguishable, they do not form monophyletic clades with commonly

120 used mitochondrial markers Cytochrome Oxidase subunit 1 (COI) and the large

121 ribosomal subunit rDNA (16S) (Black et al. 1997; McMullin et al. 2003; Andersen et al.

122 2004; Miglietta et al. 2010). COI has been suggested as a global standard to provide 
123 species level resolution in animals, hence its nickname, the "DNA barcoding" marker

124 (Herbert et al. 2003; Hajibabaei et al. 2007). However, there are limitations to using

125 barcoding molecules (see Moritz and Cicero, 2004). The inability of this marker to

126 differentiate the described Escarpia species has led to suggestions that they are either a

127 single morphologically plastic species or that there is low COI divergence between the

128 Escarpia, which may be the result of the long life spans and the slow evolutionary rate

129 seen in seep vestimentiferan mitochondrial genes (McMullin et al. 2003). The large

130 distance between populations of a single "species" would require that Escarpia offspring

131 travel thousands of kilometers along continental margins or across the Atlantic abyssal

132 plain to maintain integrity of a single panmictic population, possibly using an

133 undiscovered continuum of chemosynthetic communities as "stepping stones" (Feldman

134 et al. 1998; Cordes et al. 2007b).

135

136 Vestimentiferan larval biology

137 The investigation of life history traits in tubeworms is important for

138 understanding how speciation occurs and how seep communities are established and

139 maintained (Tyler and Young 1999). Adult vestimentiferans are sessile and have separate

140 sexes. The females are known to store sperm bundles; eggs of the seep tubeworms from

141 the upper Louisiana Slope of the Gulf of Mexico, Lamellibrachia luymesi and

142 Seepiophila jonesi, are fertilized internally, and zygotes are released into the water

143 column allowing the lecithotrophic larvae to disperse on ocean currents (Vrijenhoek

144 2010; Hilario et al. 2005). S. jonesi larvae reared in the laboratory survived for 21 days

145 before metamorphosis, suggesting a possible dispersal range of $40-60 \mathrm{~km}$ for tubeworms 
146 at < 1000m in the Gulf of Mexico (Young et al. 1996; Tyler and Young 1999). In

147 comparison, Riftia pachyptila, the giant hydrothermal vent tubeworm found on the East

148 Pacific Rise, is estimated to have dispersal distances of about $100 \mathrm{~km}$ along the ridge axis

149 with a larval lifespan of five weeks (Marsh et al. 2001).

\section{Use of molecular tools to define vestimentiferan population structure}

152 Gene flow and connectivity processes of vestimentiferans living at hydrothermal

153 vents have been the subject of several studies because the linear arrangement of vents

154 along a ridge crest provides a very tractable model system for these studies (Tunnicliffe

155 1988, Mullineaux and France, 1995; Kim and Mullineaux, 1998; Marsh et al. 2001).

156 Several authors used allozymes to uncover varying levels of genetic variation in vent

157 vestimentiferans $R$. pachyptila, Tevnia jerichonana, and Oasisia alvinae across 4000km

158 at the East Pacific Rise (Black et al. 1994; Black et al. 1998). Furthermore, Hurtado et al.

159 (2004) used mtCOI to identify subdivision in R. pachyptila across the Easter Microplate

160 Region, indicating restricted gene flow across this region.

161 Shank and Halanych (2007) proposed that genetic markers such as COI have

162 under sampled genetic diversity in R. pachyptila, and investigated genetic structure using

163 amplified fragment length polymorphisms (AFLP). With this approach, 630 polymorphic

164 loci were uncovered to identify clustering of $R$. pachyptila individuals according to

165 locality ( $9^{\circ} \mathrm{N}$ EPR, Guaymas Basin, and Southern Eastern Pacific Rise) illustrating

166 greater population subdivision than previously seen. Additionally, Vrijenhoek (2010)

167 estimated within species gene flow as high to moderate in R. pachyptila and Ridgeia

168 piscesae, which was reported as number of migrants transferred along contiguous ridge 
segments.

170 In contrast to vents, studying seep vestimentiferan connectivity is more complex

171 as regions of active hydrocarbon seepage are patchily and haphazardly distributed, often

172 in areas with very complex current regimes. McMullin et al. (2010) investigated genetic

173 structure in seep populations of L. luymesi and S. jonesi, two species that often co-occur

174 at seep sites in the northern GoM at depths $<1000 \mathrm{~m}$. Based on twelve polymorphic

175 microsatellite markers, a pattern of isolation by distance in L. luymesi and a genetic

176 clustering fitting age of aggregation in $S$. jonesi. It is, however, unclear if vestimentiferan

177 populations exhibit similar population subdivisions at seeps $>1000 \mathrm{~m}$ where the currents

178 are even less understood.

179 To better understand the scale of population connectivity and the factors affecting

180 gene flow in Escarpia, we ask 1) On a global scale, are the geographically separated

181 Escarpia taxa as genetically similar as suggested by mitochondrial sequences, or do they

182 form genetically distinct populations and 2) On a regional scale, is there evidence of

183 genetic differentiation between populations at distinct isolated sites within the GoM and

184 WACS?

185 To address the first question we used the classic mitochondrial DNA molecular

186 markers mtCOI and mt16S rRNA, supplemented with another mitochondrial (mt) gene

187 Cytochrome B (CYTB), an Exon Priming Intron Crossing (EPIC) nuclear marker

188 Hemoglobin subunit B2 intron (HbB2i), as well as nine polymorphic microsatellite loci.

189 Cytochrome B has been found to be phylogenetically informative in many groups (Johns

190 and Avise 1998). The utility of CYTB as an informative marker in deep-sea invertebrates

191 has not been investigated in detail. 
At the regional scale, the existence and pattern of effective larval dispersal versus

193 genetic divergence was addressed by analyzing 11 microsatellites on samples collected

194 from eight sampling sites in the GoM and 16 microsatellites on samples collected from

195 three sampling sites at WACS. Because all E. spicata individuals were collected from a

196 single site, a regional scale analysis was not conducted for E. spicata.

198 Methods

199 Sample Collection and Preparation

200 Tubeworms were collected via a manned submersible and remotely operated

201 vehicles (ROV) from seep sites during several research cruises occurring from 2003 to

202 2011. Escarpia laminata individuals were collected from eight locations on the Lower

203 Louisiana Slope in the Gulf of Mexico using ROV Jason II on the National Oceanic and

204 Atmospheric Administration vessel Ronald Brown or the Deep Sea Vehicle Alvin on the

205 R/V Atlantis. Escarpia southwardae individuals were retrieved from three pockmark

206 locations near the Congo River Canyon off of the west coast of Africa using ROV Victor

2076000 on the N/O Pourquoi Pas?, operated by IFREMER, France (Table 1 and Figures 2

208 and 3). Escarpia spicata individuals were collected from the Transform Fault 4 (TF4) site

209 in the Gulf of California and provided by Robert Vrijenhoek of the Monterey Bay

210 Aquarium Research Institute, USA (see Vrijenhoek et al. 2007 for details on the

211 collection localities). Sample preparation and DNA extraction protocols were performed

212 as described in Cowart et al. 2012. Tissue samples are stored at $-80^{\circ} \mathrm{C}$ and in $96 \%$ ethanol

213 in Fisher Deep Sea lab at Penn State. 


\section{Sequencing and EPIC development}

217 A 658bp fragment of mtCOI was amplified in 42 Escarpia individuals using

218 primers $\mathrm{HCO}$ and LCO (Folmer et al. 1994); a 435bp fragment of mt16S was amplified

219 in 45 individuals using primers 16Sar and 16Sbr (Palumbi 1996), and a 401bp fragment

220 of mtCYTB was amplified in 46 Escarpia and Seepiophila individuals using primers

221 Cytbf and Cytbr (Boore and Brown 2000). Cytb primers contained many degenerate

222 bases, and Escarpia specific CYTB primers were designed for this study.

223 EPIC sequencing involves designing primers in the conserved exon regions of

224 nuclear genes to sequence across the introns, and has been previously applied to clarify

225 population relations in both marine, freshwater, and terrestrial animals (Palumbi 1996,

226 Palumbi and Baker, 1994; Bierne et al. 2000; Schaeffer et al. 2003; Li et al. 2010). To

227 amplify the intron region within the hemoglobin subunit B2, the $\mathrm{HbB} 2 \mathrm{i}$ fragment was

228 first identified in $R$. piscesae, by designing PCR primers based on the cDNA sequence of

229 R. piscesae globin B2 (accession AY250083; Bailly et al. 2003). Cloning and sequencing

230 of the resulting product revealed the 550bp intron sequence. These same primers were

231 tested in R. pachyptila, and a similar analysis was conducted to obtain a $531 \mathrm{bp}$ sequence.

232 The sequences obtained from $R$. piscesae and R. pachyptila were aligned, and primers

233 were designed in the exons to flank the intron to produce a 665bp fragment in 48

234 Escarpia and Seepiophila individuals.

235 PCR reactions and gel electrophoresis were performed as described in Miglietta

236 et al. 2010 , with annealing temperature for $1.5 \mathrm{~min}$ at $50^{\circ} \mathrm{C}(\mathrm{COI}$ and $16 \mathrm{~S})$ or $52^{\circ} \mathrm{C}$

237 (CYTB and HbB2i). Purified PCR products were submitted to the Penn State Genomics 
238 Core Facility (University Park, PA) and run on 3730XL DNA sequencer.

\section{Sequence Analyses}

$240 \quad$ Gene sequences were assembled and edited using Geneious Pro v5.5.5

241 (Biomatters Ltd.), and then aligned using ClustalW (Thompson et al. 1994) and

242 MUSCLE (Edgar, 2004) implemented through the Geneious and MEGA 5.05 interfaces

243 (Tamura et al. 2011). Both ClustalW and MUSCLE gave identical alignments, and

244 ClustalW alignments were used to generate trees. All alignments were edited and

245 confirmed by eye to ensure that indel variation was scored consistently among taxa.

246 Phylogenetic analyses of the alignments were conducted in MEGA using the Maximum

247 Likelihood (ML) (Tamura and Nei 1993) methods with 1000 bootstrap replicates.

248 Between species distances were computed in MEGA using the Maximum Composite

249 Likelihood Method (Tamura et al.2004) and are measured as the number of base

250 substitutions per site. To test for the neutrality of the four genes, Tajima's D (Tajima

251 1989) statistic was estimated using Arlequin v3.5 (Schneider and Lischer 2009). Median-

252 joining haplotype networks were created using the program Network v4.611 (Bandelt et

253 al., 1999, available at www.fluxus-engineering.com).

255 Microsatellite Analyses

256 Primers and amplification conditions for the 28 polymorphic microsatellite loci 257 developed for E. laminata and E. southwardae are listed and described in Cowart et al.

2582012 (see supporting information). Different alleles at a microsatellite locus may differ

259 by the repeat length; however, a variety of genotyping errors can lead to single base pair

260 offsets in allele size determinations (Pompanon et al. 2005). To correct for motif indel 
261 mutations, we calibrated the automated allele calls from fragment analysis software with

262 actual repeat lengths by sequencing a mean of five homozygote individuals per locus to

263 verify the length of alleles (GenBank Accessions KC900290 - KC900365). When the

264 apparent allele size was offset by less than one repeat, it was binned to the nearest

265 confirmed size. This dataset was then used for all downstream analyses. When a

266 heterozygote deficiency was observed, we tested for the presence of null alleles (which

267 can be particularly high in invertebrate populations, Chapuis and Estoup, 2007) using

268 INEst v.1.0 (Chybicki and Burczyk 2009), under the Individual Inbreeding Model.

269 Arlequin was used to test for significant departures from Hardy-Weinberg

270 Equilibrium (HWE) by computing observed and expected frequencies of heterozygosity.

271 To adjust $p$-values for multiple comparisons tests, the False Discovery Rate control

272 (FDR) (Benjamini and Yekutieli 2001) was implemented in QVALUE (Storey and

273 Tibshirani 2003) executed in the statistical software R version 2.10.1 (R Development

274 Core Team 2009). To estimate genetic differentiation, Wright's $F$-statistics were

275 computed with the aid of FSTAT v.2.9.3.2 (Wright 1951; Goudet 1995); these indices

276 describe the probability that individuals from different sub- and total populations will

277 share alleles identical by descent (Weir and Cockerham 1984). For the purposes of this

278 study, individual refers to a single tubeworm, subpopulations are all individuals from

279 specific seep location and total populations refer to all individuals from a particular 280 region.

281 To compute allelic and private allele richness for each population controlled for

282 sample size, the program HP-RARE (Kalinowski 2005) was used. To illustrate

283 population structure within and between the three regions, the programs STRUCTURE 
284 v2.3.x (Pritchard et al. 2000; Pearse and Crandall 2004) and EDENetworks v.2.16

285 (Kivelä et al. in prep) were used. For STRUCTURE, independent allele frequencies and

286 admixed populations were assumed; three replicate simulations were run using various

287 values of K, with 100,000 Markov Chain Monte Carlo (MCMC) repetitions for each

288 cluster and burn-in of 10,000.

289 To assign individuals to populations while detecting the presence of hybrids as

290 linking agents between clusters, networks based on the shared allele distance were built

291 with EDENetworks. EDENetworks illustrates the distribution of genetic distances (links)

292 among agents (individuals or populations) of a system of populations, and infers the

293 clustering of sets of individuals into distinct populations or species using percolation

294 theory and without an a priori hypothesis based on their taxonomic identity or sampling

295 location (Becheler et al. 2010; Moalic et al. 2011; Rozenfeld et al. 2007, Rozenfeld et al.

296 2008). The percolation theory allows for the splitting of a fully connected network into

297 discrete clusters, and the critical threshold distance is known as the percolation threshold

298 (Dpe), an inner property of the system (Stauffer and Aharony 1994; Watts, 2004).

299 Analysis of Molecular Variance (AMOVA) (Excoffier et al. 1992) was calculated with

300 the aid of GenoDive v.2.0b22 (Meirmans and Hedrick 2011) based on population clusters

301 identified by STRUCTURE, if applicable. To test for signatures of bottlenecks or recent 302 population expansion, the program BOTTLENECK (Piry et al. 1999) was run using the 303 Two-Phase Model and the Wilcoxon sign rank test at 1000 iterations.

305 Results

306 Mitochondrial and EPIC sequence analysis 
The COI and 16S datasets included a total of 98 sequences, including 71

308 sequences of Escarpia not previously reported, and 16 sequences from Miglietta et al.

309 (2010). Seepiophila jonesi served as the outgroup taxon for both analyses. The complete

310 COI dataset consisted of a 658bp fragment amplified in 42 Escarpia and six Seepiophila

311 The complete 16S dataset consisted of a 435bp fragment amplified in 45 Escarpia and

312 five Seepiophila. All GenBank Accession numbers are located in the supporting

313 information (Table S2). As previously reported (McMullin et al. 2003; Miglietta et al

314 2010), COI and 16S phylogenies do not resolve the three described Escarpia spp.

315 (Figures S1 and S2) due to the extremely low number of haplotypes (nine haplotypes for

316 COI and only one for 16S,). A haplotype analysis of COI is shown in Figure 4 and

317 identifies the most common haplotype as shared among the three Escarpia $(\mathrm{n}=22)$, with

318 rare haplotypes shared only within a group.

319 The CYTB dataset consisted of a $401 \mathrm{bp}$ fragment amplified in 46 sequences of

320 Escarpia and S. jonesi. The CYTB phylogeny identified two separate groups within

321 Escarpia: one moderately supported clade that included E. laminata and E. spicata, from

322 which E. southwardae is separated. S. jonesi individuals form a highly supported cluster

323 outside of the Escarpia group. The CYTB haplotype network identifies a shared

324 haplotype between E. laminata and E. spicata (Figure 4), as well as three unique

325 haplotypes for E. spicata. E. southwardae exhibited one distinct haplotype different from

326 E. laminatalE. spicata by only one mutation.

327 The HbB2i dataset included 48 sequences from Escarpia and S. jonesi, and

328 consisted of a $665 \mathrm{bp}$ fragment. The HbB2i phylogeny is in agreement with the separation

329 of the described species of Escarpia, although with only moderate bootstrap support and 
330 low levels of nucleotide divergence (Figure S4). The HbB2i haplotype network also

331 identifies geographically separated haplotypes (Figure 4). The rare haplotypes present at

332 the three polymorphic genes are unique to a specific geographic region, with none of the

333 rare haplotypes shared among Escarpia spp.

334 To provide information on the demographic history occurring among the

335 Escarpia, we examined Tajima's $D$ for the three polymorphic genes tested for each group

336 separately. None of the Tajima's $D$ tests showed values significantly departing from zero

337 (Table S3). However, considering the low number of haplotypes and nucleotide

338 divergence, one should cautiously accept the null hypothesis of neutrality and

339 demographic stability given the lack of power provided by the dataset. Testing for

340 population bottlenecks allowed us to detect of significant heterozygote excesses in all

341 sites for E. southwardae and in one site for E. laminata (GC852) (see SI tables),

342 supporting the occurrence of recent demographic expansions following establishment of

343 these two populations.

345 Microsatellites identify three genetically different Escarpia groups

346 Mean summary statistics for the nine cross-species amplified microsatellite loci

347 are detailed in Table 2. A total of 229 individuals were examined across all Escarpia; 222

348 alleles were detected across all loci with the largest number of alleles at locus EL454_9

349 (35), and the smallest at EL454_71 (8) (Table S4). For E. spicata, the mean number of

350 alleles was eight, while average gene diversity spanned from 0.471 to 0.90 , with a mean

351 expected heterozygosity of 0.780 . For $E$. laminata, the mean number of alleles was 13 ,

352 while average gene diversity had a range of 0.343 to 0.921 , with a mean expected 
353 heterozygosity of 0.753 . E. southwardae had a mean number of alleles of 12 , and gene

354 diversity had a minimum of 0.262 and a maximum of 0.907 and a mean expected

355 heterozygosity of 0.753 . Of the 27 sampling location vs. locus combinations, three

356 departed significantly from HWE after FDR correction at 0.01 .

$357 \quad F_{\text {IS }}$ values were calculated across all locations, as findings identified panmictic

358 populations in each region (see results below). For $E$. spicata, the mean $F_{\text {IS }}$ value across

359 all loci was 0.194 , for E. laminata $F_{\mathrm{IS}}$ is 0.149 and E. southwardae is 0.104 (Table 2).

360 Mean allelic richness per site varied from 4.75 to 4.87 , while private allelic richness

361 ranged from 2.71 to 3.26. There was no significant difference in the average allelic and

362 private allelic richness between the three Escarpia species ( $>0.05)$.

363 Both STRUCTURE and network analyses support the occurrence of three

364 clusters of Escarpia (Figure 5), supporting the taxonomical hypothesis based on the

365 morphological descriptions. For the network analyses, at $\mathrm{Dpe}=1$ and below, three

366 clusters emerge with a significant clustering index ( $\mathrm{p}<0.001$ ). Just above Dpe $=1$, some

367 individual nodes are isolated, despite the connection of three clusters. Although

368 clustering reveals strong genetic structure among the three taxa/regions, we note that

369 below the percolation threshold, several individual genotypes are more closely related to

370 genotypes different from the morphological and geographical groups to which they were

371 assigned (Figure 5). Network analyses also identify the GoM population as the central

372 cluster, suggesting that colonization and diversification of the Escarpia occurred through

373 the GoM. $F_{\text {ST }}$ values also identified significant differentiation between the three

374 geographically distinct populations of Escarpia (Table S4). Additionally, AMOVA 
375 analyses support that the three Escarpia populations are significantly different from one

376 another $(\mathrm{p}=0.001$, Table 3$)$.

377

378 Escarpia laminata exhibits panmixia on a regional scale

379 Eleven microsatellite loci, which include three additional species-specific loci, were

380 examined in 129 E. laminata individuals from eight sites in the GoM. A total of 167

381 alleles were detected across all sites where the EL454_57 locus had the greatest number

382 of alleles at 19 (Table S7). The MC294 site had the highest mean expected

383 heterozygosity at 0.773 , while WR269 exhibited the lowest at 0.658 . While two sites at

384 locus EL454_9 departed significantly from HWE, no locus significantly deviated from

385 HWE across all sites. The global $F_{\text {IS }}$ was 0.103 , while the mean $F_{\text {IS }}$ values for each site

386 ranged from 0.083 at AT340 to 0.194 at West Florida Escarpment. Mean allelic richness

387 per site spanned from 4.60 to 5.54 , while private allelic richness ranged from 0.22 to 0.49

388 and there was no significant difference in the average allelic and private allelic richness

389 between the eight sites $(p>0.05)$.

STRUCTURE analyses did not detect any genetic clustering on a regional scale

391 among the eight sites in the GoM. Furthermore, none of the 28 pairwise population

392 comparisons were significantly different after correction for multiple tests $(p>0.05)$.

393 The global $F_{\text {ST }}$ value was low (0.007) with a $p$-value of 0.053 , suggesting very limited

394 structure on the regional scale (Table S8). AMOVA testing identified a significant among

395 individual component, for which $8.9 \%$ of the total variance is explained $(\mathrm{p}=0.001)$

396 (Table 3). Maximum genetic differentiation was observed between AC601 and MC294,

397 sites that are separated by a distance of $657 \mathrm{~km}$, although the maximum distance between 
398 sites tested here is $980 \mathrm{~km}$. These findings indicate that gene flow is not correlated with

399 geographic distance on the regional scale in the GoM.

400

401 Escarpia southwardae is panmixic at WACS

402 Sixteen microsatellite loci were examined in 80 E. southwardae individuals from

403 three sampling sites at WACS. A total of 223 alleles were detected across the three sites,

404 and locus ES454_31 exhibited the highest number of alleles at 19 (Table S9). The Worm

405 Hole site exhibited the highest mean expected heterozygosity at 0.709 , while Regab had

406 the lowest at 0.658 . Three sites departed from HWE at loci ES454_32 and 45. The global

$407 \quad F_{\text {IS }}$ was 0.104 , while the mean $F_{\text {IS }}$ values for each population ranged from 0.081 at Worm

408 Hole to 0.149 at Baboon. Mean allelic richness per site spanned from 8.63 to 9.44, while

409 private allelic richness ranged from 1.42 to 1.68 , and there was no significant difference

410 in the average allelic and private allelic richness among the three locations. None of the

411 pairwise comparisons showed significant differentiation among populations; the global

$412 \quad F_{\mathrm{ST}}$ value was low $(0.003)$ and we did not detect any difference between the three

413 populations studied here $(\mathrm{p}=0.149$; Table $\mathrm{S} 9)$.

414 As with the E. laminata, STRUCTURE analyses of E. southwardae did not detect

415 any genetic clustering among the three sites at WACS. AMOVA testing identified a

416 significant among individual component, for which as little as $0.49 \%$ of the variance is

417 explained $(\mathrm{p}=0.002)$.

418

419 Discussion 
Results obtained in this study show that despite the isolated and haphazard

421 distribution of cold seep sites, there is panmixia over extensive regional scales. In

422 contrast, we find only limited indications of gene flow among the three regions studied.

423 These findings confirm the divergence of tubeworm populations between the three

424 regions, and suggest the presence of mechanisms that prevent or severely limit gene flow

425 across these spatial scales. However, in the absence of either experimental data

426 confirming reproductive isolation or evidence of maintenance of genetic isolation in co-

427 occurring populations, it is not possible to confirm that these differentiated populations

428 represent biologically distinct species.

\section{Barriers to gene flow across large scales}

431 Although mitochondrial DNA is often used in the taxonomic identification of

432 animals, neither the "barcoding marker" COI, nor the16S rRNA gene, resolved the

433 relationships among the three described species of Escarpia. Furthermore, the mtCYTB

434 gene could only resolve the Escarpia into two groups, rather than three. The HbB2i

435 locus, together with microsatellites, supports the existence of three differentiated groups,

436 corresponding to the taxonomic hypothesis based on morphological and geographic

437 criteria.

438 The fixed haplotypes and low diversities at mitochondrial and nuclear loci are an

439 indication that strong demographic fluctuations occurred in the recent past and reduced

440 the level of polymorphism. The lack of allele frequency variation in mtDNA among

441 geographically separate populations could result from a number of factors. First, there

442 may be insufficient time since the separation of populations. Second, as evolutionary rate 
443 is influenced by species generation time, populations with longer generation times may

444 accumulate mutations at a slower rate (Hartl and Clark, 2007). As seep vestimentiferans

445 can live for hundreds of years (Bergquist et al. 2000), their long generation time could

446 contribute to the lack of mutations seen in mtDNA. Third, the low mutation rates may be

447 the result of vestimentiferans having efficient mutation repair systems. Additionally, the

448 exclusively maternal transmission of mtDNA reflects on the distribution of maternal

449 lineages rather than whole genome evolution, and possible differences between male and

450 female effective population sizes may induce different rates of evolution of mitochondrial

451 versus nuclear genomes. Finally, selective sweeps may interfere with the usual mutation-

452 drift balance and influence mitochondrial evolution, as organelles have smaller effective

453 population sizes and are more prone to genetic drift (Bazin et al. 2006; Galtier et al. 2009;

454 Moalic et al. 2012). Whether these populations are the result of recent founder events

455 followed by genetic drift and ultimately differentiation, or from a more ancient

456 colonization that was followed by divergence among protospecies or species remains

457 unknown. The lack of shared rare haplotypes at the mitochondrial loci is consistent with

458 either. Regardless, gene flow is clearly very limited between the regions inhabited by the

459 described Escarpia spp.

460 Vestimentiferans are thought to have arisen around 100 million years ago (Black

461 et al. 1997). As recently as 3.5 million years ago, deep-water flows connecting the Pacific

462 and Atlantic oceans were disrupted by the formation of the Isthmus of Panama as the

463 North American, South American and Caribbean plates converged (Keigwin 1978;

464 Knowlton 1993). Additionally, the deep water that flows from the Caribbean Sea into the

465 GoM is trapped by geologic sills occurring below $800 \mathrm{~m}$ in the Florida Straits and below 
$4661900 \mathrm{~m}$ in the Yucatan Channel, which may help to further isolate biological populations

467 in the GoM from other parts of the Atlantic (Welsh and Inoue 2000; Rivas et al. 2005).

468 All three Escarpia populations experience similar habitat conditions, including the high

469 pressure that accompanies extreme depth, as well as elevated concentrations of hydrogen

470 sulfide required by their chemoautotrophic symbionts (Childress and Fisher, 1992).

471 Therefore, the genetic divergence and morphological variation reported here are likely

472 not driven by habitat specialization, although, whether differences in morphology are

473 influenced by phenotype plasticity or selective pressures remains to be investigated.

474 The relatively low levels of genetic differentiation reported, and the presence of

475 rare haplotypes that are unshared between described species, supports the existence of a

476 recent common ancestor, and possibly recent colonization events into different ocean

477 basins. The genetic differentiation between the three Escarpia is possibly the result of a

478 genetic drift and lack of gene exchange due to geographic and reproductive isolation. The

479 analyses here indicate that contemporary migration between the three provinces, if

480 occurring at all, is low. Species delimitation is difficult to demonstrate with

481 geographically separated taxa (de Queiroz 2007). The best method to confirm the

482 presence of reproductive barriers among potentially distinct species would be controlled

483 crosses, which at this time are technically difficult to conduct with these deep sea taxa.

484 However, based on the congruence of morphological differences with data from a nuclear

485 gene and other polymorphic loci, as well as the large distances separating the described

486 species, we suggest that the mitochondrial genetic data should not be used to suggest that

487 the three described species are in fact a single species. We do caution that in the absence

488 of data on reproductive isolation it is also possible that the three described species 
489 represent either separate populations of the same species with scarce and/or highly

490 sporadic gene flow or protospecies undergoing strict divergence and on the way to

491 speciation.

492 On a regional scale, the evidence for panmixia suggests that despite the

493 occurrence of isolated seep sites, Escarpia do have the ability to connect across

494 geographic scales of nearly 1000k in the GoM and at least $120 \mathrm{~km}$ at WACS. The low

495 divergence seen across sampling locations suggests that contemporary gene flow is

496 occurring at the regional scale for both GoM and WACS.

497

498 The influence of deep currents on dispersal and recruitment of Escarpia

499 In addition to constraints imposed by larval biology, successful dispersal of

500 marine larvae depends on movement with ocean currents (Scheltema 1968; Johnson and

501 Black 1984). The moderately high dispersal potential of vestimentiferan larvae, coupled

502 with deep currents, can account for the open exchange of migrants seen within the GoM

503 and WACS regions. Currents below 1000m are often quite complex, moving in various

504 directions and speeds (Hamilton, 1990). In the GoM, the Loop Current (LC) dominates

505 the east, and while restricted to $<1000 \mathrm{~m}$ depth, the LC sheds warm eddies that generate

506 and influence deep Topographic Rossby Waves (TRW) at depths below 1000m

507 (Hamilton 1990). Swirl speeds of deep eddies are estimated to range from 10 to $21 \mathrm{~cm} \mathrm{~s}^{-1}$

508 at $2550 \mathrm{~m}$, increasing speed with more complex topography (Welsh and Inoue 2000), and

509 TRW are estimated to occasionally move at speeds of $15-30 \mathrm{~cm} / \mathrm{s}^{-1}$, having durations

510 from 20 - 30 days and dominating the central and western GoM (Chelton and Shelax

511 1996; Oye and Lee 2002; Hamilton 2007). 
512 Thermal tolerances of deep sea larvae also play an important role in dispersal, as

513 larvae moving into shallower waters and thus warmer temperatures can experience

514 changes in metabolism and feeding rates, influencing the amount of time they spend in

515 the water column (Young et al 1996; Young et al. 1998). McMullin et al. (2010) and

516 Young et al. (2012) found that most larvae of the shallower living GoM tubeworm,

517 Lamellibrachia.luymesi, are retained in the same general geographic location as the

518 adults, not dispersing $>300 \mathrm{~km}$ from the source populations. Additionally, L. luymesi are

519 unable to tolerate the temperatures at depths above the thermocline, further restricting the

520 propagules to the region.

521 The speeds of deep currents, accompanied by prolonged larval duration, as well as

522 the lower temperatures needed for larval development, appear to be sufficient to transport

523 Escarpia migrants to habitats across the GoM sea floor at depths below 1000m.

524 Additionally, there are more than 50 known chemosynthetic sites distributed across the

525 GoM (Mineral Management Service, 2006). This along with model data of closely related

526 species suggests that GoM Escarpia do have the ability to colonize seeps across the

527 regional distance described in this study.

528 A major feature of the West African continental margin is the Congo deep-sea

529 river fan, which results from loads of sediment transported and deposited by the Congo

530 River (Khripounoff et al. 2003; Sibuet and Vangriesheim 2009). The submarine fan

531 ranges in depth from 3400 to $4800 \mathrm{~m}$ and contributed to the formation of the cold seep

532 habitats that are home to E. southwardae (Vangriesheim et al. 2009). Deep-sea

533 circulation at the Congo River fan is complex, and below 2000m, and currents have a

534 southeastward migration path (Stramma and England 1999). At Regab, current speeds 
535 range from 8.9 to $12.3 \mathrm{~cm} \mathrm{~s}^{-1}$, rarely exceeding $10 \mathrm{~cm} \mathrm{~s}^{-1}$ (Vangriesheim et al. 2009).

536 Despite the relatively slow movement of currents in this region, the three sampling sites

537 encompass a distance of less than $150 \mathrm{~km}$, and if larval characteristics are comparable to

538 other seep vestimentiferans, gene flow across these sites is realistic.

\section{Conclusions}

541 In this study, we used the analyses of several molecular genetic markers to

542 support the occurrence of three genetically distinct entities that correspond to three

543 Escarpia species described based on morphology from the Gulf of Mexico, the eastern

544 Atlantic, and the eastern Pacific. This data suggests limitations to large-scale dispersal

545 by Escarpia larvae and are in agreement with a scenario of ongoing divergence after

546 relatively recent colonization in the three regions. However, the widespread genetic

547 homogeneity observed within regions over hundreds of kilometers also support recurrent

548 events of moderate scale dispersal. Finally, the lack of resolution seen in three mtDNA

549 loci contrasts with the lineage and genotype sorting revealed by the nuclear datasets (one

550 intron and several microsatellite loci). This suggests that EPIC and microsatellite markers

551 can serve as tools to not only examine population structure within groups, but also to

552 clarify boundaries and distributions of species with very low levels of divergence in

553 classic bar coding genes.

\section{Acknowledgements}

556 We would like to thank the following people for their contribution to this project:

557 captains, crews and expedition leaders of the ROVs Jason II and Victor 6000, the US 
558 deep submergence facility, DSV Alvin, R/V Atlantis, N/O Pourquoi Pas?, the NOAA

559 vessel Ronald Brown; Robert Vrijenhoek and his laboratory at the Monterey Bay

560 Aquarium Research Institute, Kenneth Halanych, Drew Wham, Karine Olu - Le Roy (as

561 the chief of the WACS oceanographic cruise), Kimberlyn Nelson, Iliana Baums, Todd

562 LaJeunesse, Ann Andersen, Stéphane Hourdez, Pen-yuan Hsing, Annelies De Groote,

563 Olivier Soubigou, Miles Saunders, Andrew Mendelson, Howard Fescemyer, Nicholas

564 Polato, Meghann Durante and Andre Wallace. This research was funded in part by the

565 National Science Foundation (Award \# 1209688), the National Oceanographic

566 Partnership Program (NOPP) through support from the Bureau of Ocean Energy

567 Management contracts \#M05PC00018 and \#M08PC20038 (TDI Brooks International

568 Prime), the National Oceanic and Atmospheric Administration's Office of Ocean

569 Exploration and Research (NOAA OER), Penn State Eberly College of Science, and an

570 Alfred P. Sloan Scholarship to DAC. Any opinions, findings, conclusions, or

571 recommendations expressed in this article are those of the authors and do not necessarily

572 reflect the views of the National Science Foundation.

573

\section{Authors Contributions}

575 DAC: provided funding for research, performed research, analyzed data, wrote

576 manuscript

577 COH: performed research, edits to manuscript

578 SAH: performed data analyses, edits to manuscript

579 SLC: performed data analyses, edits to manuscript

580 CRF: provided ideas for research, provided funding for research, edits to manuscript 
581 SWS: provided laboratory equipment and space for research to be conducted,

582 interpretation of data, edits to manuscript

583

\section{References}

585 Andersen, AC, Hourdez, S, Marie, B, Jollivet, D, Lallier, FH, Sibuet, M (2004) Escarpia

586 southwardae sp nov., a new species of vestimentiferan tubeworm (Annelida,

587 Siboglinidae) from West African cold seeps. Canadian Journal of Zoology-Revue

588 Canadienne De Zoologie, 82, 980 - 999.

589

590 Anderson, RK, Scalan, RS, Parker, PL, Behrens, EW (1983) Seep oil and gas in Gulf of

591 Mexico slope sediments. Science, 222, 619 - 621.

592

593 Bailly, X, Leroy, R, Carney, S, Collin, O, Zal, F, Toulmond, A, and Jollivet, D. (2003)

594 The loss of the hemoglobin $\mathrm{H}_{2} \mathrm{~S}$-binding function in annelids from sulfide-free habitats

595 reveals molecular adaptation driven by Darwinian positive selection. Proceedings of the

596 National Academy of Sciences, USA, 100: 5885 - 5890.

597

598 Bandelt, HJ, Forster, P, Röhl, A (1999) Median-joining networks for inferring

599 intraspecific phylogenies. Molecular Biology and Evolution, 16:37 - 48.

600

601 Bazin, E, Glémin, S, Galtier, N (2006) Population size does not influence mitochondrial 602 genetic diversity in animals. Science, 312 (5773), 570 - 572.

603 
604 Becheler, R, Diekmann, O, Hily, C, Moalic, Y, Arnaud-Haond, S (2010) The concept of 605 population in clonal organisms: mosaics of temporally colonized patches are forming 606 highly diverse meadows of Zostera marina in Brittany. Molecular Ecology, 19, 2394 $607 \quad 2407$

608

609 Benjamini, Y, Yekutieli, D (2001) The control of the false discovery rate in multiple 610 testing under dependency. Annals of statistics, 29,1165 - 1188.

611

612 Bergquist, DC, Williams, FM, Fisher, CR (2000) Longevity record for deep-sea

613 invertebrate. Nature, 403, 499 - 500.

614

615 Bergquist, D, Ward, T, Cordes, EE, McNelis, T, Howlett, S, Kosoff, R, Hourdez, S,

616 Carney, R, Fisher, CR (2003) Community structure of vestimentiferan-generated habitat

617 islands from Gulf of Mexico cold seeps. Journal of Experimental Marine Biology and

618 Ecology, 289 (2) $197-222$.

619

620 Bierne, N, Lehnert, SA, Bedier, E, Bonhomme, F, Moore, SS (2000) Screening for

621 intron-length polymorphisms in penaeid shrimps using exon-primed intron-crossing

622 (EPIC)-PCR. Molecular Ecology, 9(2), 233 - 235.

623

624 Black, MB, Halanych, KM, Maas, PAY, Hoeh, WR, Hashimoto, J, Desbruyères, D, Lutz, 625 RA, Vrijenhoek, RC (1997) Molecular systematics of vestimentiferan tubeworms from 626 hydrothermal vents and cold-water seeps. Marine Biology, 130, 141 - 149. 
627 Black, MB, Lutz, RA, Vrijenhoek, RC (1994) Gene flow among vestimentiferan tube

628 worm (Riftia pachyptila) populations from hydrothermal vents of the eastern Pacific.

629 Marine Biology, 120(1), 33 - 39.

630

631 Black, MB, Trivedi, A, Maas, PA, Lutz, RA, Vrijenhoek, RC (1998) Population genetics 632 and biogeography of vestimentiferan tube worms. Deep-Sea Research Part II, 45(1-3), $633365-382$.

634

635 Boore, JL, Brown, WM (2000) Mitochondrial Genomes of Galathealinum, Helobdella, 636 and Platynereis: Sequence and Gene Arrangement Comparisons Indicate that

637 Pogonophora Is Not a Phylum and Annelida and Arthropoda Are Not Sister Taxa.

638 Molecular Biology and Evolution, 17, 87 - 106.

639

640 Brooks JM, Kennicutt MC, Fisher CR, Macko, SA, Cole, K, Childress, JJ, Bidigare, RR, 641 Vetter, RD (1987) Deep-sea hydrocarbon seep communities - evidence for energy and 642 nutritional carbon sources. Science ,238, 1138-1142.

643

644 Chapuis, M, Estoup, A (2007) Microsatellite null allele and estimation of population

645 differentiation. Molecular Biology and Evolution, 24, 621 - 631.

646

647 Chelton, DS, Schlax, MG (1996) Global observations of oceanic Rossby waves. Science, $648 \quad 272,234-238$.

649 
650 Childress, JJ, Fisher, CR (1992) The biology of hydrothermal vent animals - physiology,

651 biochemistry and autotrophic symbioses. Oceanography and Marine Biology 30, 337 -

652441.

653

654 Chybicki, I, Burczyk, J (2009) Simultaneous estimation of null alleles and inbreeding 655 coefficients. Journal of Heredity, 100, 106 - 113.

656

657 Cordes, EE, Carney, SL, Hourdez, S, Carney, RS, Brooks, JM, Fisher, CR (2007) Cold

658 seeps of the deep Gulf of Mexico: Community structure and biogeographic comparisons

659 to Atlantic equatorial belt seep communities. Deep-Sea Research Part I-Oceanographic

660 Research Papers, 54, 637 - 653.

661

662 Cordes EE, Bergquist DC, Redding MR, Fisher CR. 2007. Growth of Seepiophila jonesi: a

663 second species of long-lived vestimentiferan. Marine Ecology, 28:160-68

664

665 Cordes, EE, Bergquist, DC, Fisher, CR (2009) Macro-Ecology of Gulf of Mexico Cold

666 Seeps. Annual Review of Marine Science, 1, 143 - 168.

667

668 Cowart, DA, Huang, C, Schaeffer, SW. Identification and amplification of microsatellite

669 loci in deep-sea tubeworms of the genus Escarpia (Polychaeta, Siboglinidae).

670 Conservation Genetics Resources, 5, 479 - 482

671

672 De Queiroz, K. (2007). Species concepts and species delimitation. Systematic Biology, 56

673 (6), 879-886. 
674 Edgar, RC (2004) MUSCLE: multiple sequence alignment with high accuracy and high 675 throughput. Nucleic Acids Research, 32(5), 1792-1797.

676

677 Etter, RR, Rex, MA, Chase, MC, Quattro, JM (1999) A genetic dimension to deep-sea 678 biodiversity. Deep-Sea Research Part I, 46, 1095 - 1099.

679

680 Excoffier, L, Smouse, P, Quattro, J (1992) Analysis of molecular variance inferred from 681 metric distances among DNA haplotypes: Application to human mitochondrial DNA 682 restriction data. Genetics, 131, 479 - 491. 683

684 Feldman, RS, Shank, TM, Black, MB, Baco, AR, Smith, CR, Vrijenhoek, RC (1998)

685 Vestimentiferan on a Whale Fall. Biological Bulletin, 194, 116 - 119.

686

687 Fisher, C, Roberts, H, Cordes, E, Bernard, B (2007) Cold Seeps and Associated 688 Communities of the Gulf of Mexico. Oceanography, 20, 118 - 129. 689

690 Folmer, O, Black, M, Hoeh, W, Lutz, R, Vrijenhoek, R (1994) DNA primers for 691 amplification of mitochondrial cytochrome c oxidase subunit I from diverse metazoan 692 invertebrates. Molecular Marine Biology and Biotechnology, 3, 294 - 299. 693

694 Freytag, JK, Girguis, PR, Bergquist, DC, Andras, JP, Childress, JJ, Fisher, CR (2001) A 695 paradox resolved: Sulfide acquisition by roots of seep tubeworms sustains net 696 chemoautotrophy. Proceedings of the National Academy of Sciences, 98, 13408 - 13413. 
697 Galtier, N, Nabholz, N, Glémin, S, Hurst GDD (2009) Mitochondrial DNA as a marker 698 of molecular diversity: a reappraisal. Molecular Ecology 18, 4541 - 4550.

699

700 Gardiner, SL, McMullin, E, Fisher, CR (2001) Seepiophila jonesi, a new genus and 701 species of vestimentiferan tube worm (Annelida : Pogonophora) from hydrocarbon seep

702 communities in the Gulf of Mexico. Proceedings of the Biological Society of Washington,

$703 \mathbf{1 1 4}, 694-707$.

704

705 Goudet, J (1995) FSTAT (Version 1.2): A computer program to calculate F-Statistics.

706 The Journal of Heredity, 86, 485 - 486.

707

708 Haas, A, Peckmann, J, Elvert, M, Sahling, H, Bohrmann, G (2010) Patterns of carbonate 709 authigenesis at the Kouilou pockmarks on the Congo deep-sea fan. Marine Geology, 268, $710 \quad 129-136$.

711

712 Hajibabaei, M, Singer, GAC, Hebert, PDN, Hickey, DA (2007) DNA barcoding: how it

713 complements taxonomy, molecular phylogenetics and population genetics. Trends in

714 Genetics, 23, $167-172$.

715

716 Hamilton, P (1990) Deep currents in the Gulf of Mexico. Journal of Physical

717 Oceanography 20, $1180-1207$.

718 
719 Hamilton, P (2007) Deep-Current Variability near the Sigsbee Escarpment in the Gulf of

720 Mexico. Journal of Physical Oceanography, 37, 708 - 726.

721

722 Hartl, DL, Clark, AG (2007) Principals of population genetics, fourth edition. Sinauer

723 Associates, Inc. Publishers, Sunderland, Massachusettes

724

725 Hebert, PDN, Ratnasingham, S, de Waard, JR (2003) Barcoding animal of life:

726 cytochrome c oxidase subunit 1 divergences among closely related species. Proceedings

727 of the Royal Society of London B, 270, S96 - S99.

728

729 Hedgecock D, Barber PH, Edmands S (2007) Genetic approaches to measuring

730 connectivity. Oceanography-Washington DC-Oceanography Society, 20, 70 - 79

731

732 Hilario, AY, Young, CM, Tyler, PA (2005) Sperm Storage, Internal Fertilization, and

733 Embryonic Dispersal in Vent and Seep Tubeworms (Polychaeta:Siboglinidae:

734 Vestimentifera). Biological Bulletin, 208, 20 - 28.

735

736 Hurtado, LA, Lutz, RA, Vrijenhoek, RC (2004) Distinct patterns of genetic

737 differentiation among annelids of eastern Pacific hydrothermal vents. Molecular Ecology,

738 13(9), $2603-2615$.

739

740 Jackson, J (1974) Biogeogrpahic consequences of eurytopy and stenotopy among marine

741 bivalves and their evolutionary significance. The American Naturalist, 108, 541 - 560. 
743 Johns, GC, Avise, JC (1998) A Comparative Summary of Genetic Distances in the

744 Vertebrates from the Mitochondrial Cytochrome b Gene. Molecular Biology and

745 Evolution, 15, $1481-1490$.

746

747 Jones, M (1985) On the Vestimentifera, new phylum: six new species, and other taxa,

748 from hydrothermal vents and elsewhere. Bulletin of the Biological Society of Washington,

$749 \quad(6), 117-158$.

750

751 Johnson, MS, Black, R (1984) Pattern Beneath the Chaos: The Effect of Recruitment on

752 Genetic Patchiness in an Intertidal Limpet. Evolution 38(6), 1371 - 1383.

753

754 Julian, D, Gaill, F, Wood, E, Arp, AJ, Fisher, CR (1999) Roots as a site of hydrogen

755 sulfide uptake in the hydrocarbon seep vestimentiferan. Lamellibrachia sp. Journal of

756 Experimental Biology, 202, 2245 - 2257.

757

758 Kalinowski, S (2005) HP-RARE 1.0: a computer program for performing rarefaction on

759 measures of allelic richness. Molecular Ecology Resources, 5, 187 - 189.

760

761 Keigwin, L (1978) Pliocene closing of the Isthmus of Panama, based on biostratigraphic

762 evidence from nearby Pacific Ocean and Caribbean Sea cores. Geology, 6, 630 - 634.

763 
764 Khripounoff, A, Vangriesheim, A, Babonneau, N, Crassous, P, Dennielou, B, Savoye, B 765 (2003) Direct observation of intense turbidity current activity in the Zaire submarine

766 valley at $4000 \mathrm{~m}$ water depth. Marine Geology, 194, 151 - 158.

767

768 Kim, SL, Mullineaux, LS (1998) Distribution and near-bottom transport of larvae and

769 other plankton at hydrothermal vents. Deep Sea Research II, 45.1 - 3, 423 - 440.

770

771 Kivelä, M, Arnaud-Haond, S, Saramäki, J. EDENetwork: Ecological and Evolutionary

772 Networks. in prep.

773

774 Knowlton, N (1993) Sibling species in the sea. Annual Review in Ecological Systematics, $775 \quad 24,189-216$.

776

777 Li, C, Riethoven, J JM, Ma, L (2010) Exon-primed intron-crossing (EPIC) markers for 778 non-model teleost fishes. BMC evolutionary biology, 10(1), 90.

779

780 Marsh, AM, Mullineaux, LS, Young, CM, Manahan, DT (2001) Larval dispersal

781 potential of the tubeworm Riftia pachyptila at deep-sea hydrothermal vents. Nature, 411 782 (6838), $77-80$.

783

784 McMullin, ER, Hourdez, S, Schaeffer, SW, Fisher, CR (2003) Phylogeny and

785 biogeography of deep sea vestimentiferan tubeworms and their bacterial symbionts.

786 Symbiosis, 34, 1 - 41. 
787 McMullin, E, Nelson, K, Fisher, CR, Schaeffer, SW (2010) Population structure of two 788 deep sea tubeworms, Lamellibrachia luymesi and Seepiophila jonesi, from the 789 hydrocarbon seeps of the Gulf of Mexico. Deep-Sea Research Part I, 57, 1499 - 1509. 790

791 Meirmans, P, Hedrick, PW (2011) Assessing population structure: FST and related 792 measures. Molecular Ecology Resources, 11, 5 - 18.

793

794 Miglietta, M, Hourdez, S, Cowart, DA, Schaeffer, SW, Fisher, CR (2010) Species

795 boundaries of Gulf of Mexico vestimentiferans (Polychaeta, Siboglinidae) inferred from 796 mitochondrial genes. Deep-Sea Research Part II, 57, 1916 - 1925.

797

798 Minerals Management Service Gulf of Mexico OR (2006) Gulf of Mexico OCS Oil and 799 Gas Lease Sales: 2007-2012. Western Planning Area Sales 204, 207, 210, 215, and 218.

800 Central Planning Area Sales 205, 206, 208, 213, 216, and 222. Draft Environmental

801 Impact Statement. Volume II, pp. 1 - 170, Figure 173-179, page 115. U.S. Department of 802 the Interior.

803

804 Moalic, Y, Arnaud-Haond, S, Perrin, C, Pearson, GA, Serrao, EA (2011) Travelling in 805 time with networks: Revealing present day hybridization versus ancestral polymorphism 806 between two species of brown algae, Fucus vesiculosus and F. spiralis. BMC 807 Evolutionary Biology, 11(1), 33.

808 
809 Moalic, Y, Desbruyères, D, Duarte, CM, Rozenfeld, AF, Bachraty, C, Arnaud-Haond, S

810 (2012) Biogeography Revisited with Network Theory: Retracing the History of

811 Hydrothermal Vent Communities. Systematic Biology, 61(1), 127 - 137.

812

813 Moritz C, Cicero C (2004) DNA Barcoding: Promise and Pitfalls. PLoS Biology 2(10),

814 e354, $1529-1531$.

815

816 Mullineaux, LS, France, SC (1995) Dispersal mechanisms of deep-sea hydrothermal vent

817 fauna. Geophysical Monograph Series, 91, 408 - 424.

818

819 Oey, LY, Lee, HC (2002) Deep eddy energy and topographic Rossby Waves in the Gulf

820 of Mexico. Journal of Physical Oceanography, 32(12). 3527 - 3499.

821

822 Olu-Le Roy, K, Caprais, JC, Fifis, A, Fabri, MC, Galeron, J, Budzinsky, H, Le Menach,

823 K, Khripounoff, A, Ondréas, H, Sibuet, M (2007) Cold-seep assemblages on a giant

824 pockmark off West Africa: spatial patterns and environmental control. Marine Ecology,

$82528,115-130$.

826

827 Olu, KC, Cordes, EE, Fisher, CR, Brooks, JM, Sibuet, M, Desbruyères, D (2010)

828 Biogeography and Potential Exchanges Among the Atlantic Equatorial Belt Cold-Seep

829 Faunas. Public Library of Science One (PLoS), 5, 1 - 11.

830 
831 Ondréas, H, Olu, K, Fouquet, Y, Charlou, JL, Gay, A, Dennielou, B, Donval, JP, Fifis, A, 832 Nadalig, T, Cochonat, P, Cauquil, E, Bourillet, JF, Le Moigne, M, Sibuet, M (2005) ROV 833 study of a giant pockmark on the Gabon continental margin. Geo-Marine Letters, 25, 281 $834-292$.

835

836 Palumbi, S (1992) Marine speciation on a small planet. Trends in Ecology and Evolution, $837 \quad 7,114-118$.

838

839 Palumbi, S (1994) Genetic divergence, reproductive isolation, and marine speciation.

840 Annual Review in Ecological Systematics, 25, 547 - 572.

841

842 Palumbi SR (1996) Nuclei Acids II: The Polymerase Chain Reaction. Molecular 843 Systematics, pages 205 - 247 (ed. Hillis DM, Moritz, C., Mable, B.K.). Sinauer

844 Associates, Inc., Sunderland, Massachusettes

845

846 Palumbi, SR, Baker, CS (1994) Contrasting population structure from nuclear intron 847 sequences and mtDNA of humpback whales. Molecular Biology and Evolution, 11(3), $848 \quad 426-435$.

849

850 Pearse, DC, Crandall, KA (2004) Beyond Fst: Analysis of population genetic data for 851 conservation. Conservation Genetics, 5, 585 - 602.

852 
853 Piry, S, Luikart, G, Cornuet, JM (1999) Computer note. BOTTLENECK: a computer

854 program for detecting recent reductions in the effective size using allele frequency data.

855 Journal of Heredity, 90 (4), 502 - 503.

856

857 Pompanon, F, Bonin, A, Bellemain, E, Taberlet, P (2005) Genotyping errors: causes,

858 consequences and solutions. Nature Reviews: Genetics, 6, 847 - 860.

859

860 Pritchard, JS, Stephens, M, Donnelly, P (2000) Inference of Population Structure Using

861 Multilocus Genotype Data. Genetics, 155, 945 - 959.

862

863 R Development Core Team (2009). R: A language and environment for statistical

864 computing. R Foundation for Statistical Computing,Vienna, Austria. ISBN 3-900051-07-

865 0, URL http://www.R-project.org.

866

867 Rivas DB, Badan, A, Ochoa, J (2005) The ventilation of the deep Gulf of Mexico.

868 Journal of Physical Oceanography, 35, 1763 - 1781.

869

870 Roberts HA, P (1994) Hydrocarbon-derived carbonate buildups of the northern Gulf of

871 Mexico continental slope: a review of submersible investigations. Geo-Marine Letters,

872 14, $135-148$. 
873 Roberts HH, Carney R, Kupchik M, Fisher CR, Nelson K, Becker E, Goehring L,

874 Lessard-Pilon S, Telesnicki, G, Bernard B, Brooks JM, Bright M, Cordes E, Hourdez S,

875 Hunt J, Shedd W, Boland G, Joye S, Samarkin V, Bernier M, Bowles M, MacDonald I,

876 Niemann H, Petersen C, Morrison C, Potter, J (2007) ALVIN explores the deep northern

877 Gulf of Mexico slope. Eos Transactions American Geophysical Union, 88:341-42

878

879 Rozenfeld, AF, Arnaud-Haond, S, Hernández-García, E, Eguíluz, VM, Matías, M A,

880 Serrão, E, Duarte, CM (2007) Spectrum of genetic diversity and networks of clonal

881 organisms. Journal of the Royal Society Interface, 4(17), 1093-1102.

882

883 Rozenfeld, AF, Arnaud-Haond, S, Hernández-García, E, Eguíluz, VM, Serrão, E A,

884 Duarte, CM (2008) Network analysis identifies weak and strong links in a

885 metapopulation system. Proceedings of the National Academy of Sciences, 105 (48),

$88618824-18829$.

887

888 Sassen, R, Roberts, HH, Aharon, P, Larkin, J, Chinn, EW, Carney, R (1993)

889 Chemosynthetic bacterial mats at cold hydrocarbon seeps, Gulf of Mexico continental

890 slope. Organic Geochemistry, 20, 77 - 89.

891

892 Sassen, R, MacDonald, IR, Requejo, AG, Guinasso, NL, Kennicutt, MC, Sweet, ST,

893 Brooks, JM (1994a) Organic geochemisty of sediments from chemosynthetic

894 communities, Gulf of Mexico slope. Geo-Marine Letters, 14, 110 - 119.

895 
896 Schaeffer SW, Goetting-Minesky SWP, Graybill JL, Miller JM, Kim K, Miller JG,

897 Anderson WW (2003) Evolutionary genomics of inversions in Drosophila

898 pseudoobscura: Evidence for epistasis. Proceedings of the National Academy of Sciences

899 USA 100: 8319-8324.

900

901 Scheltema, R (1968) Dispersal of larvae by equatorial ocean currents and its importance

902 to the zoogeography of shoal-water tropical species. Nature, 217, $1159-1162$.

903

904 Schneider, S, Lischer, H (2009) ARLEQUIN, version 3.5. An integrated software

905 package for population genetics data analysis. University of Berne, Berne.

906

907 Shank, TH, Halanych, KM (2007) Toward a mechanistic understanding of larval

908 dispersal: insights from genomic fingerprinting of the deep-sea hydrothermal vent

909 tubeworm Riftia pachyptila. Marine Ecology, 28, 25 - 35.

910

911 Sibuet, M, Vangriesheim, A (2009) Deep-sea environment and biodiversity of the West

912 African Equatorial margin. Deep-Sea Research Part II: Topical Studies in

913 Oceanography, 56, $2156-2168$.

914

915 Stauffer D, Aharony A (1994) Introduction to Percolation Theory, Francis T, editor.

916 London. CRC Press, Taylor \& Francis

917 
918 Storey, JD, Tibshirani, R (2003) Statistical significance for genomewide studies.

919 Proceedings of the National Academy of Sciences, 100 (16), 9440 - 9445.

920

921 Stramma, L, England, M (1999) On the water masses and mean circulation of the South

922 Atlantic Ocean. Journal of Geophysical Research, 104, 20.

923

924 Tajima, F (1989) Statistical method for testing the neutral mutation hypothesis by DNA 925 polymorphism. Genetics, 123 (3) 585 - 595.

926

927 Tamura, K, Nei, M. (1993) Estimation of the number of nucleotide substitutions in the

928 control region of mitochondrial DNA in humans and chimpanzees. Molecular Biology

929 and Evolution, 10, 512 - 526.

930 Tamura, K, Nei, M, Kumar, S (2004) Prospects for inferring very large phylogenies by

931 using the neighbor-joining method. Proceedings of the National Academy of Sciences of

932 the United States of America, 101, 11030 - 11035.

933

934 Tamura, K, Peterson, D, Perterson, N, Stecher, G, Nei, M, Kumar, S (2011) MEGA5:

935 Molecular Evolutionary Genetics Analysis using Maximum Likelihood, Evolutionary

936 Distance, and Maximum Parsimony Methods. Molecular Biology and Evolution, 28,

$9372731-2739$.

938 
939 Thompson, JD, Higgins, DG, Gibson, TJ (1994) CLUSTAL W: improving the sensitivity

940 of progressive multiple sequence alignment through sequence weighting, position-

941 specific gap penalties and weight matrix choice. Nucleic Acids Research, 22, 1.

942

943 Tunnicliffe, V (1988) Biogeography and evolution of hydrothermal-vent fauna in the

944 eastern Pacific Ocean. Proceedings of the Royal Society of London B, 233, 347 - 366.

945

946 Tyler, PY, Young, CM (1999) Reproduction and dispersal at vents and cold seeps.

947 Journal of Marine Biological Association of the U.K. 79, 193 - 208.

948

949 Vangriesheim, A, Khripounoff, A, Crassous, P (2009) Turbidity events observed in situ

950 along the Congo submarine channel. Deep-sea Research II, 56, 2208 - 2222.

951

952 Vrijenhoek, RC (2010) Genetic diversity and connectivity of deep-sea hydrothermal vent

953 metapopulations. Molecular Ecology, 19, 4391 - 4411.

954

955 Vrijenhoek, RC, Duhaime, M, Jones, WJ (2007) Subtype Variation Among Bacterial

956 Endosymbionts of Tubeworms (Annelida: Siboglinidae) from the Gulf of California.

957 Biological Bulletin, 212, 180 - 184.

958

959 Vrijenhoek, RS, Schutz, SJ, Gustafson, RG, Lutz, RA (1994) Cryptic species of deep-sea

960 clams (Mollusca: Bivalvia: Vesicomyidae) from hydrothermal vent and cold-water seep

961 environments. Deep-Sea Research I, 41, 1171 - 1189. 
962 Wares, JG, Gaines, SD, Cunningham, CW (2001) A comparative study of asymmetric

963 migration events across a marine biogeographic boundary. Evolution, 55, 295 - 306.

964

965 Watts DJ (2004) The "new" science of networks. Annual Review of Sociology, 30, 243-

966270.

967

968 Weir, B, Cockerham, CC (1984) Estimating F-statistics for the analysis of population

969 structure. Evolution, 38, 1358 - 1370.

970

971 Welsh, S, Inoue, M (2000) Loop Current rings and the deep circulation in the Gulf of

972 Mexico. Journal of Geophysical Research, 105, 951 - 959.

973

974 Wright, S (1951) The genetic structure of populations. Annual Eugeneics, 15, 323 - 354.

975

976 Young, CM, Vazquez, E, Metaxas, A, Tyler, PA (1996) Embryology of vestimentiferan

977 tubeworms from deep-sea methane/sulphide seeps. Nature, 381, 514 - 516.

978

979 Young, CM, Ekaratne, SUK, Cameron, JL. 1998. Thermal tolerances of embryos and

980 planktotrophic larvae of Archaeopneustes hystrix (Spatangoidea) and Stylocidaris lineata

981 (Cidaroidea), bathyal echinoids from the Bahamian Slope. Journal of Experimental

982 Marine Biology and Ecology, 223,65 - 76.

983 
984 Young, CM, He, R, Emlet, RB, Li, Y, Qian, H, Arellano, SM, Gaest, AV, Bennett, KC,

985 Wolf, M, Smart, TI, Rice, ME (2012). Dispersal of deep-sea larvae from the Intra-

986 American seas: simulations of trajectories using ocean models. Integrative and

987 Comparative Biology, 52(4), 483 - 496.

988

989

990

991

992

993

994

995

996

997

998

999

1000

1001

1002

1003 Figure 1: A, Aggregation of Escarpia southwardae, at the Worm Hole site on the West

1004 African coast (Photo complements of IFREMER, WACS campaign, dive 430).. B,

1005 Anterior portion, dorsal view of E. southwardae tubeworm, reprinted with permission

1006 from Andersen et al., 2004. AR: axial rod; BL: branchial lamellae; CG: ciliated groves

1007 (males); DG: dorsal groove; DVM: dorsal vestimental wings; O: obturaculum; T: trunk;

1008 V: vestimentum. NRC Research Press License \# 2960880817425

1009

1010 Figure 2: Gulf of Mexico (GoM) cold seep sites sampled for this study. 1000 meter

1011 contours from NASA-JPL Advanced Spaceborne Thermal Emission and Reflection

1012 Radiometer (http://www.geomapapp.org).

\section{Data Accessibility} KC900290 - KC900365

Sequence alignments and phylogenetic trees: Tree Base submission numbers 14129,

of collection, deep sea vehicle, dive number, coordinates, depth, collection method, morphotype, tissue sample and preservation method): Dryad doi:10.5061/dryad.586b5

\section{Figure Legends}


1014 Figure 3: West African cold seep sites sampled for this study. 1000 meter contours from

1015 NASA-JPL Advanced Spaceborne Thermal Emission and Reflection Radiometer

1016 (http://www.geomapapp.org).

1017

1018 Figure 4: Median-joining haplotype networks of the COI, CYTB and HbB2i genes.

1019 Colors represent Escarpia regions (described species) (red: E. laminata from the Gulf of

1020 Mexico, blue: E. southwardae from west coast of Africa and green: E. spicata from the

1021 Gulf of California. Sizes of haplotype circles and are proportional to the number of

1022 individuals possessing the same sequence and each line represents one mutational change

1023 separating two haplotypes.

1024

1025 Figure 5: Top: STRUCTURE results (admixture model, three replicate runs) for three

1026 putative species of Escarpia vestimentiferan tubeworms based on nine microsatellite

1027 markers. Each vertical bar represents an individual tubeworm. The y-axis is the

1028 proportion of each individual's genotype belonging to a distinct population cluster.

1029 Bottom: Network topologies of E. laminata (red), E. spicata (green) and E. southwardae

1030 (blue) individuals with the Shared Allele Distance (SAD) based on nine microsatellite

1031 markers. Only links with value smaller than or equal to the percolation distances are

1032 present. Nodes (circles) represent individuals. Three clusters are identified, one for each

1033 of the described Escarpia species and their respective geographic regions. 
A

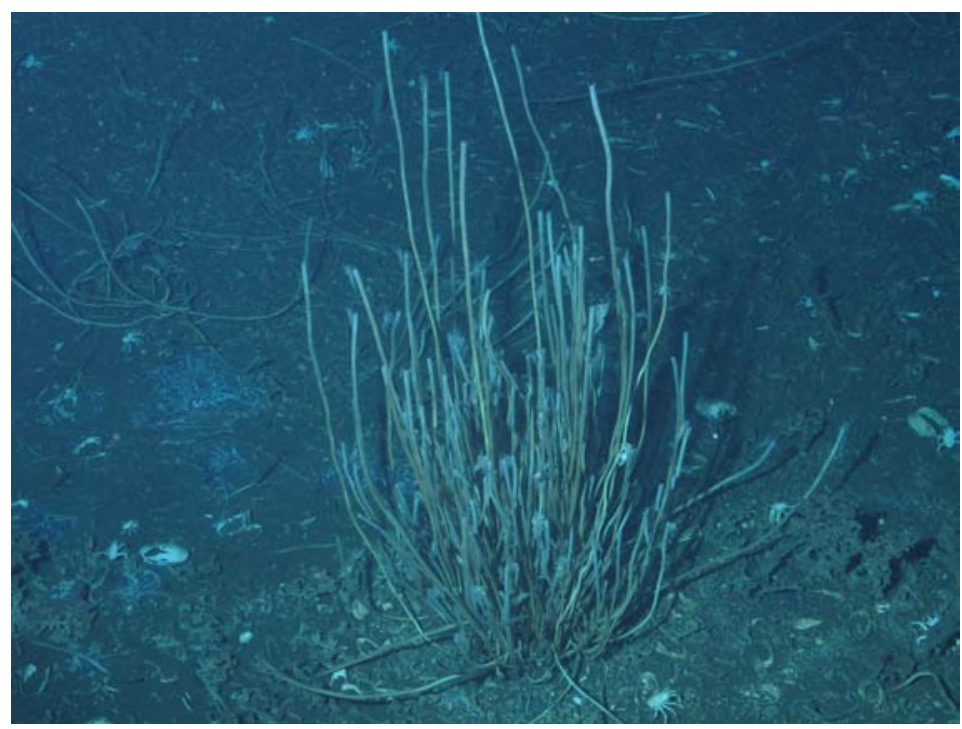

B

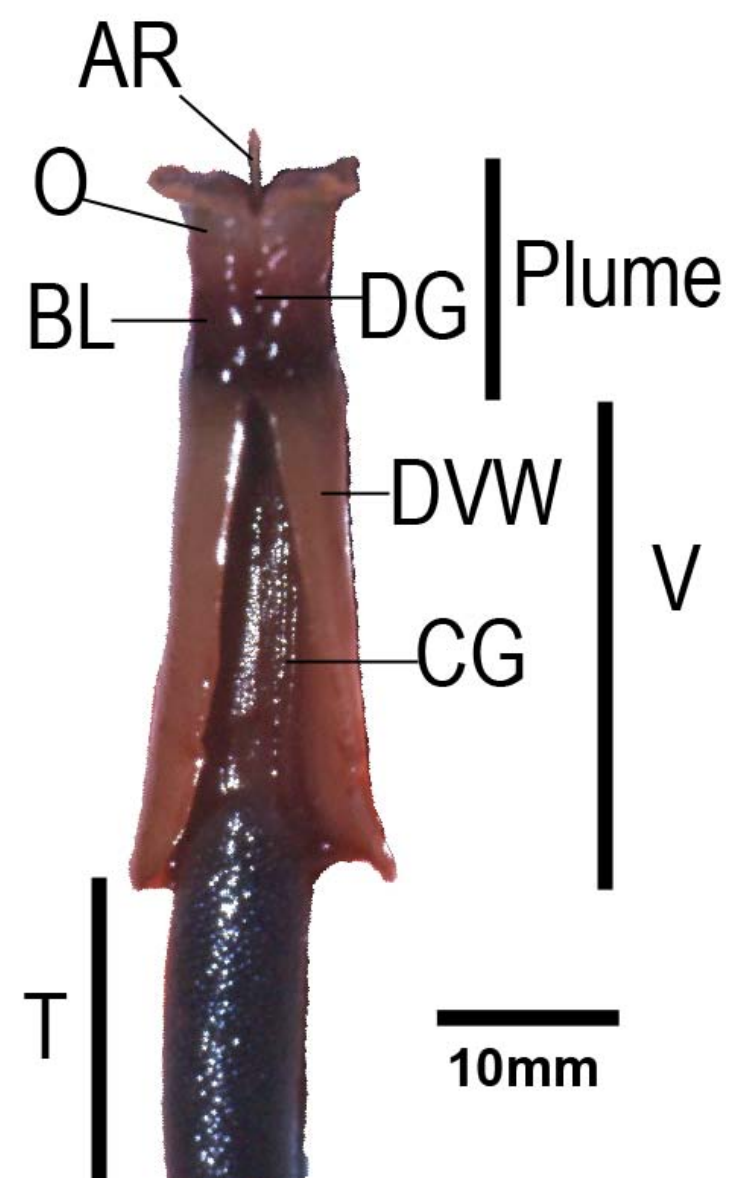




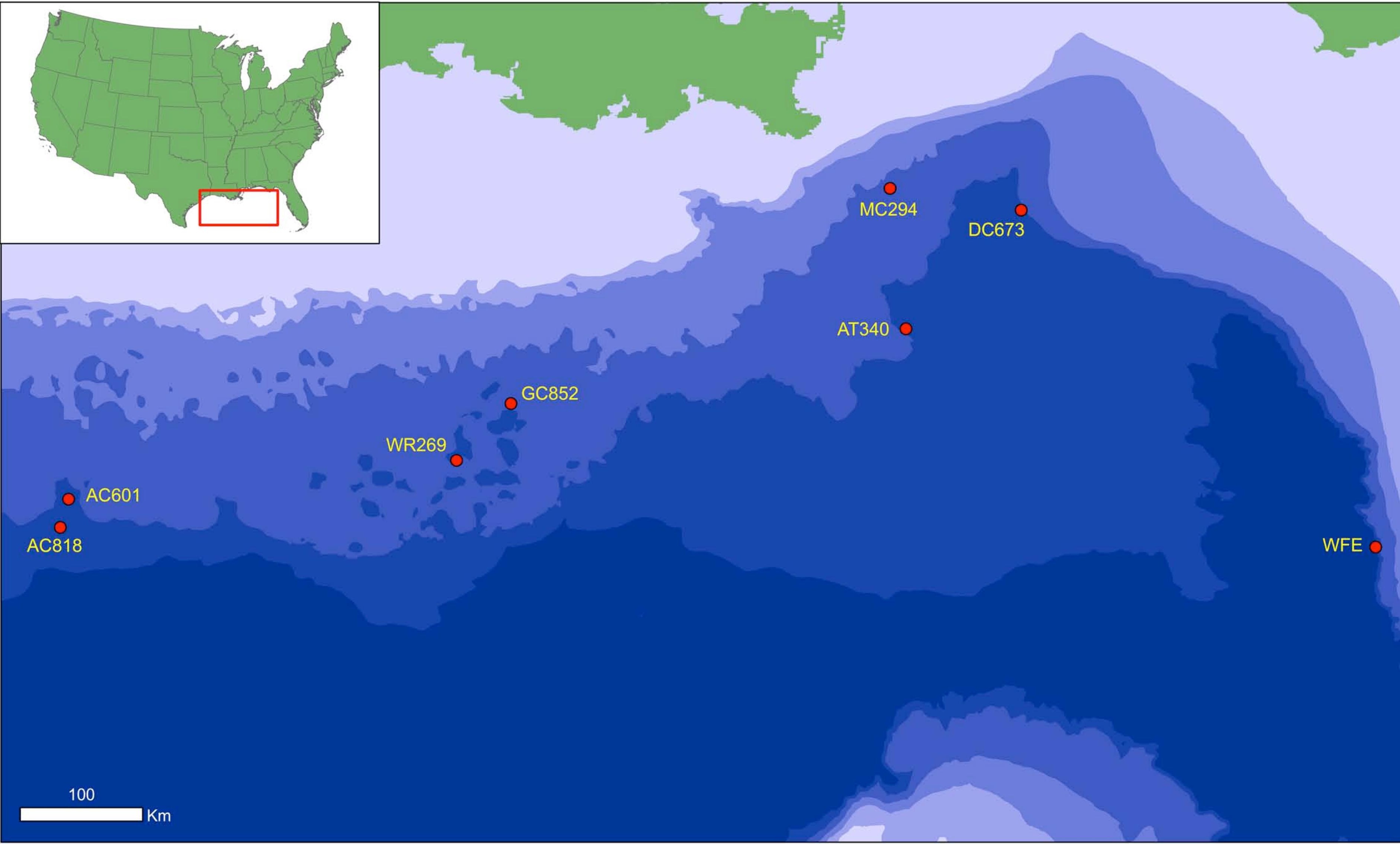




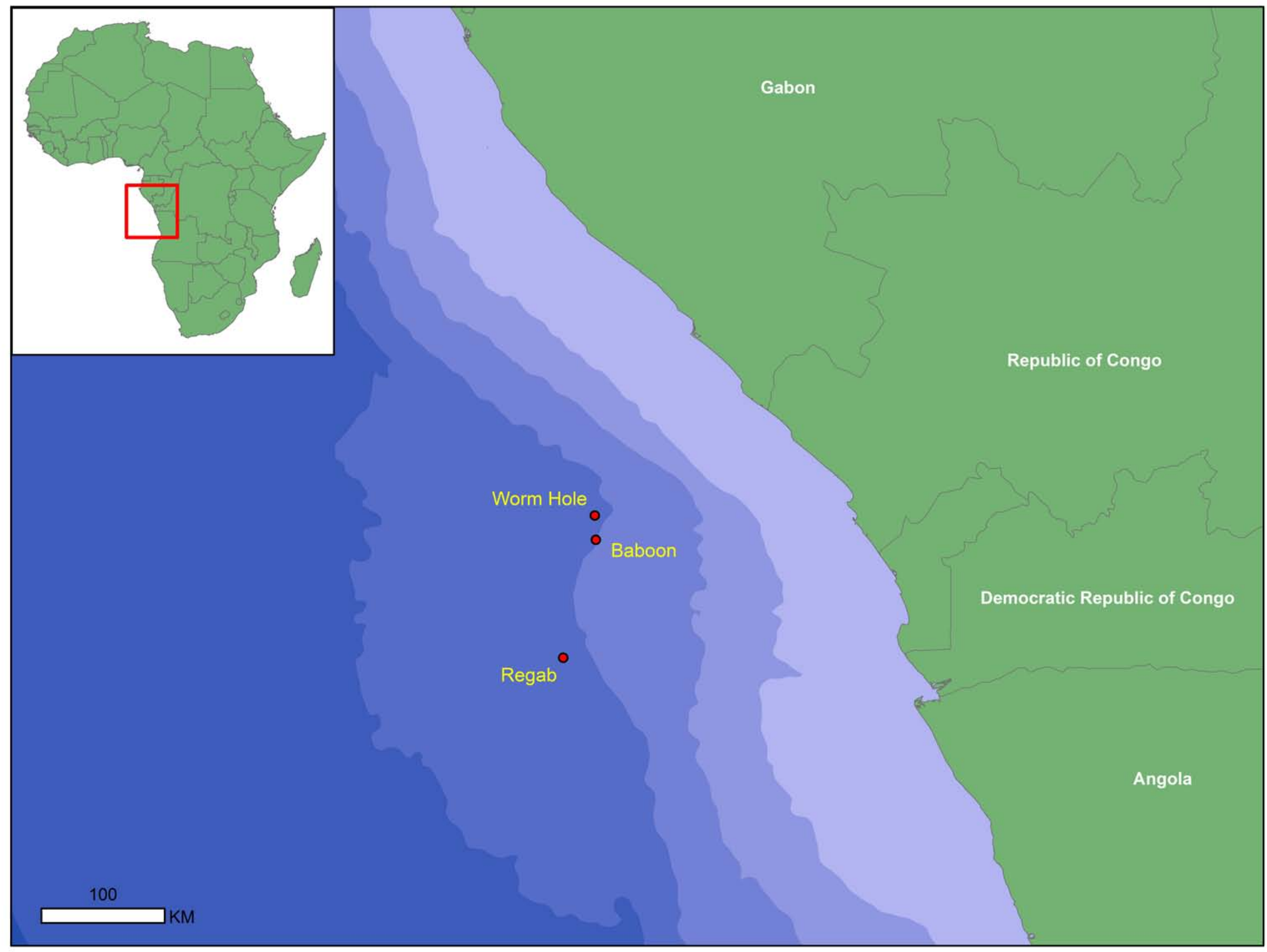


mtcol

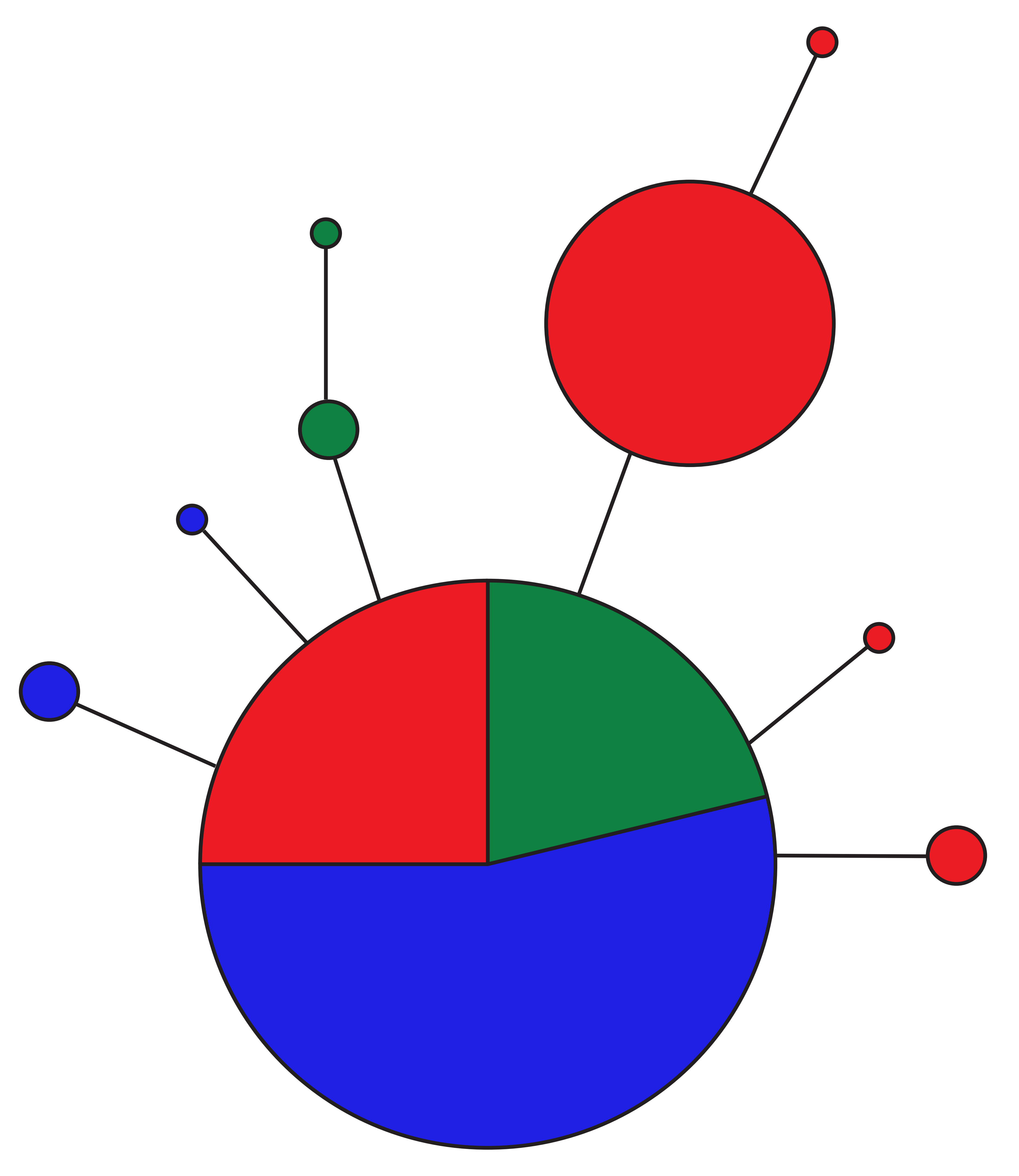

mtCYTB

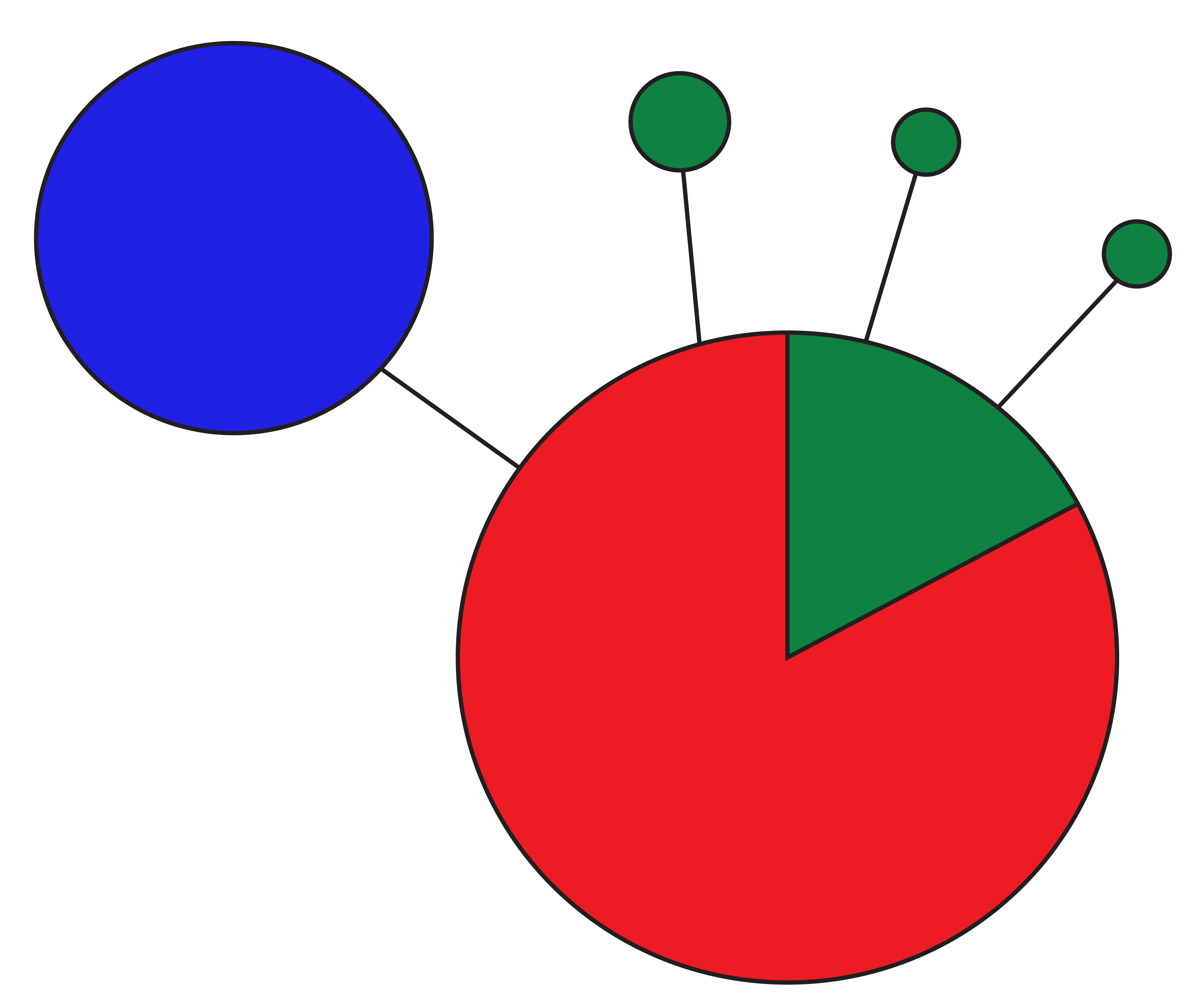

HbB2i

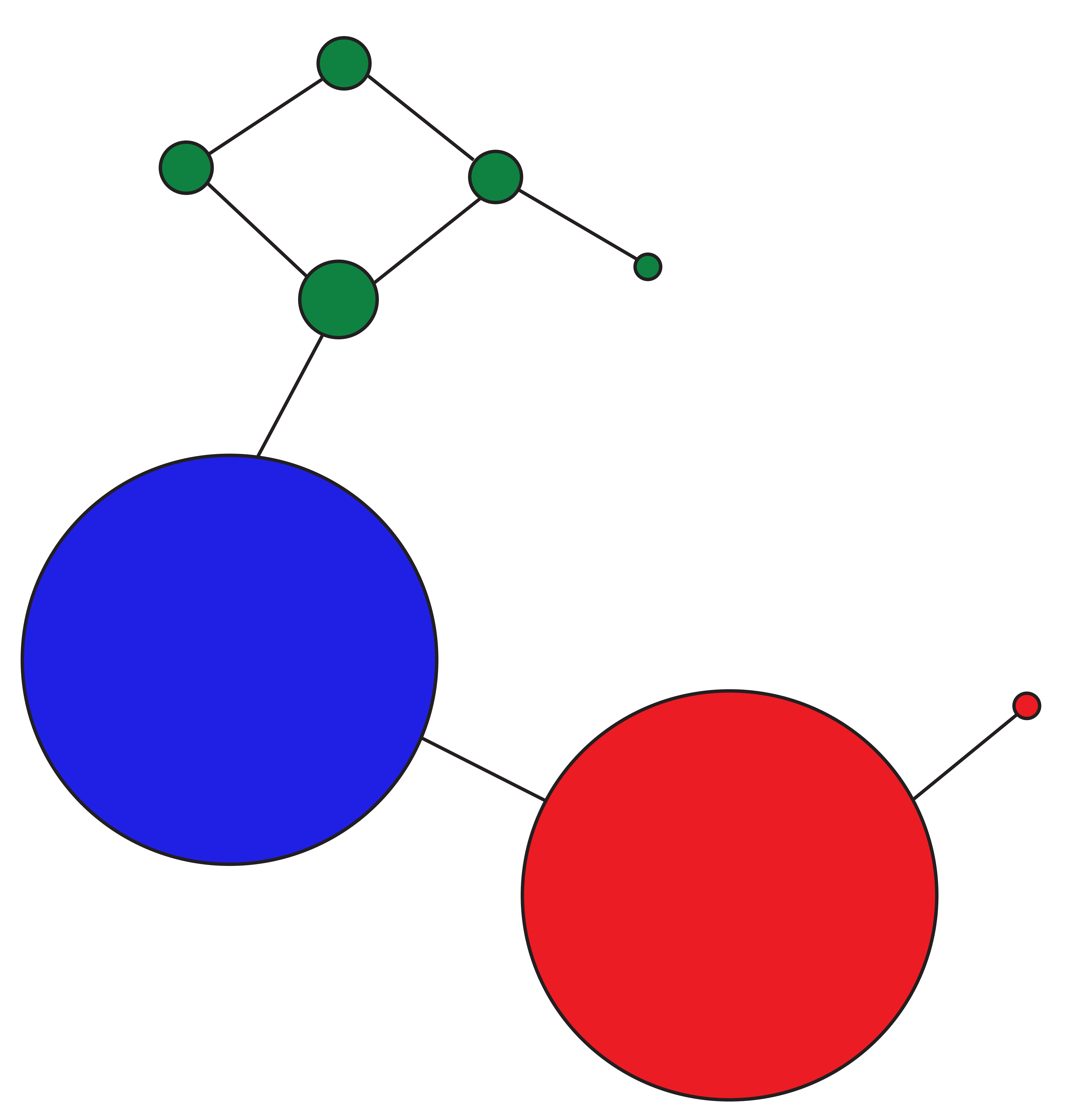




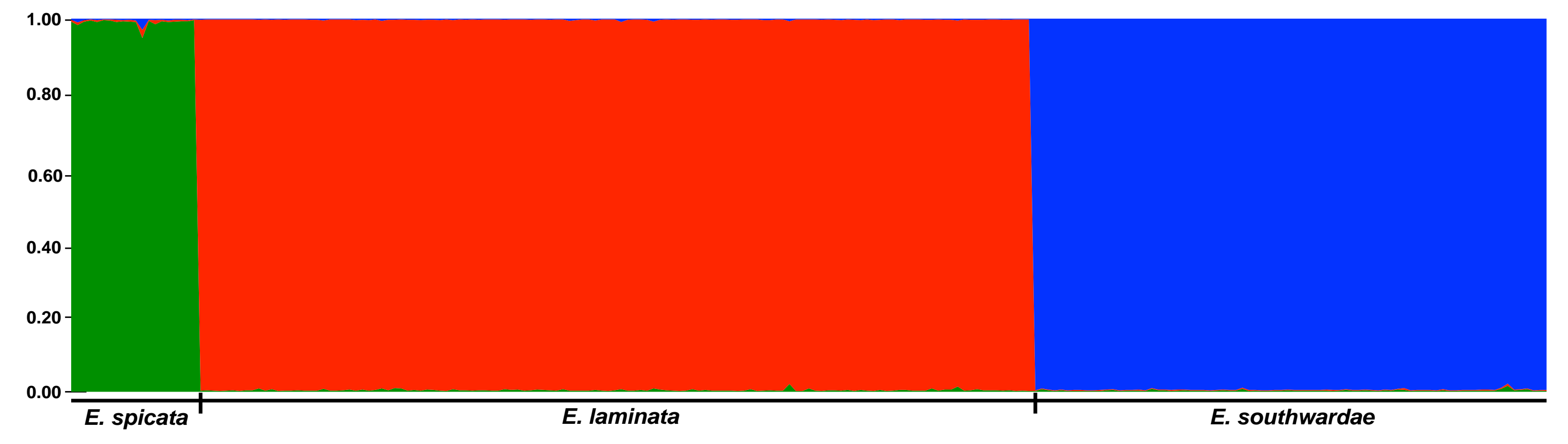
Dpe $=1.15$
Dpe $=1.00$
Dpe $=0.99$
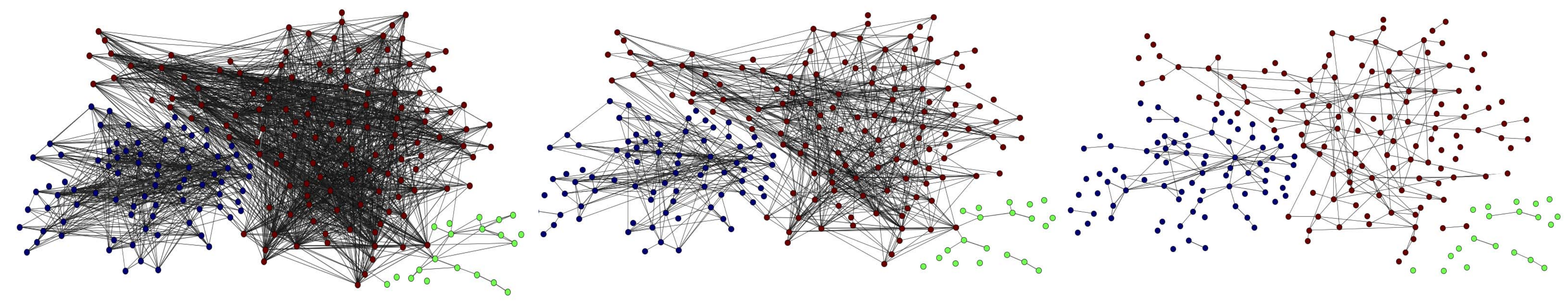
Table 1: Locations of seep sites sampled for this study. $N$ refers to the number of individuals collected and region refers to location from which the collections were made: Gulf of California (GoC), Gulf of Mexico (GoM), West African Cold Seeps (WACS).

\begin{tabular}{|c|c|c|c|c|c|c|}
\hline Provisional Species & Seep Name & Latitude & Longitude & Depth (m) & $N$ & Region \\
\hline $\begin{array}{c}\text { Escarpia spicata } \\
n=20\end{array}$ & TF4 & $27.357^{\circ} \mathrm{N}$ & $111.290^{\circ} \mathrm{W}$ & 1784 & 20 & $\mathrm{GoC}$ \\
\hline \multirow{8}{*}{$\begin{array}{l}\text { Escarpia laminata } \\
\quad n=129\end{array}$} & AC601 & $26.392^{\circ} \mathrm{N}$ & $94.514^{\circ} \mathrm{W}$ & 2335 & 12 & GoM \\
\hline & AC818 & $26.185^{\circ} \mathrm{N}$ & $94.574^{\circ} \mathrm{W}$ & 2744 & 8 & GoM \\
\hline & WR269 & $26.677^{\circ} \mathrm{N}$ & $91.665^{\circ} \mathrm{W}$ & 1975 & 7 & GoM \\
\hline & GC852 & $27.095^{\circ} \mathrm{N}$ & $91.265^{\circ} \mathrm{W}$ & 1437 & 11 & GoM \\
\hline & AT340 & $27.644^{\circ} \mathrm{N}$ & $88.365^{\circ} \mathrm{W}$ & 2204 & 11 & GoM \\
\hline & MC294 & $28.675^{\circ} \mathrm{N}$ & $88.481^{\circ} \mathrm{W}$ & 1800 & 8 & GoM \\
\hline & DC673 & $28.516^{\circ} \mathrm{N}$ & $87.518^{\circ} \mathrm{W}$ & 2604 & 42 & GoM \\
\hline & $\begin{array}{l}\text { West Florida } \\
\text { Escarpment }\end{array}$ & $26.040^{\circ} \mathrm{N}$ & $84.915^{\circ} \mathrm{W}$ & 3304 & 30 & GoM \\
\hline \multirow{3}{*}{$\begin{array}{l}\text { Escarpia southwardae } \\
\qquad n=80\end{array}$} & Worm Hole & $4.760^{\circ} \mathrm{S}$ & $9.941^{\circ} \mathrm{E}$ & 3189 & 25 & WACS \\
\hline & Baboon & $4.937^{\circ} \mathrm{S}$ & $9.949^{\circ} \mathrm{E}$ & 3128 & 28 & WACS \\
\hline & Regab & $5.798^{\circ} \mathrm{S}$ & $9.711^{\circ} \mathrm{E}$ & 3153 & 27 & WACS \\
\hline
\end{tabular}


Table 2: Summary statistics for 28 microsatellite loci amplified in three described Escarpia species.

\begin{tabular}{|c|c|c|c|c|c|c|c|c|}
\hline \multirow{2}{*}{$\begin{array}{c}\text { Escarpia taxa } \\
(9 \text { loci })\end{array}$} & \multicolumn{8}{|c|}{ Summary Statistics (means across all loci) } \\
\hline & $N_{A}$ & $H_{O}$ & $H_{E}$ & $F_{I S}$ & $A R$ & $A R^{S E}$ & $P_{A R}$ & $P_{A R}^{S E}$ \\
\hline E. spicata & 8 & 0.690 & 0.780 & 0.194 & 4.750 & 0.376 & 2.71 & 0.447 \\
\hline E. laminata & 13 & 0.681 & 0.753 & 0.149 & 4.870 & 0.490 & 3.24 & 0.668 \\
\hline E. southwardae & 12 & 0.702 & 0.753 & 0.104 & 4.780 & 0.445 & 3.26 & 0.700 \\
\hline Escarpia laminata & \multicolumn{8}{|c|}{ Summary Statistics (means across all loci) } \\
\hline (11 loci) & $N_{A}$ & $H_{O}$ & $H_{E}$ & $F_{I S}$ & $A R$ & $A R^{S E}$ & $P_{A R}$ & $P_{A R}^{S E}$ \\
\hline AC601 & 7.3 & 0.615 & 0.686 & 0.171 & 5.120 & 0.747 & 0.260 & 0.102 \\
\hline AC818 & 5.1 & 0.602 & 0.693 & 0.191 & 4.460 & 0.560 & 0.300 & 0.104 \\
\hline WR269 & 5.7 & 0.658 & 0.725 & 0.182 & 5.260 & 0.688 & 0.230 & 0.094 \\
\hline GC852 & 6.7 & 0.626 & 0.682 & 0.151 & 5.100 & 0.598 & 0.400 & 0.132 \\
\hline AT340 & 6.6 & 0.680 & 0.720 & 0.083 & 4.990 & 0.594 & 0.330 & 0.108 \\
\hline MC388 & 6.4 & 0.670 & 0.773 & 0.179 & 5.160 & 0.629 & 0.540 & 0.175 \\
\hline DC673 & 10.8 & 0.645 & 0.702 & 0.186 & 5.250 & 0.664 & 0.380 & 0.106 \\
\hline WFE & 9.7 & 0.612 & 0.702 & 0.194 & 5.250 & 0.644 & 0.420 & 0.126 \\
\hline Escarpia & \multicolumn{8}{|c|}{ Summary Statistics (means across all loci) } \\
\hline (16 loci) & $N_{A}$ & $H_{O}$ & $H_{E}$ & $F_{I S}$ & $A R$ & $A R^{S E}$ & $P_{A R}$ & $P_{A R}{ }^{S E}$ \\
\hline Regab & 8.7 & 0.618 & 0.658 & 0.100 & 8.630 & 0.904 & 1.420 & 0.310 \\
\hline Wormhole & 9.4 & 0.685 & 0.709 & 0.081 & 9.440 & 1.151 & 1.530 & 0.390 \\
\hline Baboon & 9.2 & 0.636 & 0.664 & 0.149 & 8.930 & 1.101 & 1.680 & 0.520 \\
\hline
\end{tabular}

Abbreviations: number of alleles observed across all loci $\left(N_{A}\right)$, mean observed $\left(H_{O}\right)$ and expected $\left(H_{E}\right)$ heterozygosity, mean Wright's Inbreeding Coefficient $\left(F_{I S}\right)$, mean rarified allelic richness $(A R)$ and standard error $\left(\mathrm{AR}^{\mathrm{SE}}\right)$; private allele richness $\left(P_{A R}\right)$ and standard error $\left(\mathrm{P}_{\mathrm{AR}}{ }^{\mathrm{SE}}\right)$. Rarefied over 20 samples and means are not significantly different $(\mathrm{P}>0.05)$. 
Table 3: Summary of Analysis of Molecular Variance (AMOVA) conducted for each study under the Infinite Allele Model, F $_{\text {ST }}$ Significance (*) was tested using 1000 permutations. Results for Stepwise Mutation Model ( $\left.\mathrm{R}_{\mathrm{ST}}\right)$ are congruent with IAM. Abbreviations: d.f, degrees of freedom; SS, sum of squares.

\begin{tabular}{|c|c|c|c|c|c|}
\hline Study & $\begin{array}{l}\text { Source of } \\
\text { Variation } \\
\end{array}$ & d.f. & SS & Variation $(\%)$ & p-value \\
\hline \multirow{3}{*}{$\begin{array}{l}\text { Escarpia Question } \\
\text { (Three species) }\end{array}$} & Within individuals & 229 & 718.50 & 80.60 & --- \\
\hline & Among individuals & 226 & 838.40 & 7.30 & $0.001 *$ \\
\hline & Among populations & 2 & 126.80 & 12.10 & $0.001 *$ \\
\hline \multirow{3}{*}{ Escarpia laminata } & Within individuals & 129 & 499.00 & 90.70 & --- \\
\hline & Among individuals & 121 & 558.01 & 8.90 & $0.001 *$ \\
\hline & Among populations & 7 & 37.12 & 0.05 & 0.053 \\
\hline \multirow{3}{*}{ Escarpia southwardae } & Within individuals & 80 & 411.50 & 94.80 & --- \\
\hline & Among individuals & 77 & 437.29 & 0.49 & $0.002 *$ \\
\hline & Among populations & 2 & 12.82 & 0.03 & 0.149 \\
\hline
\end{tabular}


Figure S1: COI maximum likelihood (ML) tree for 42 Escarpia and five Seepiophila, with fragment size of 658bp. 34 Escarpia sequences are newly isolated. Seepiophila jonesi is the outgroup taxon, and GenBank accession numbers follow the species name. Bootstrap support (1000 replicates, Tamura-Nei model) is located either above or below the node. Scale is measured as number of substitutions per nucleotide site. ML and NJ produced congruent trees for all genes, and only the ML trees are reported here.

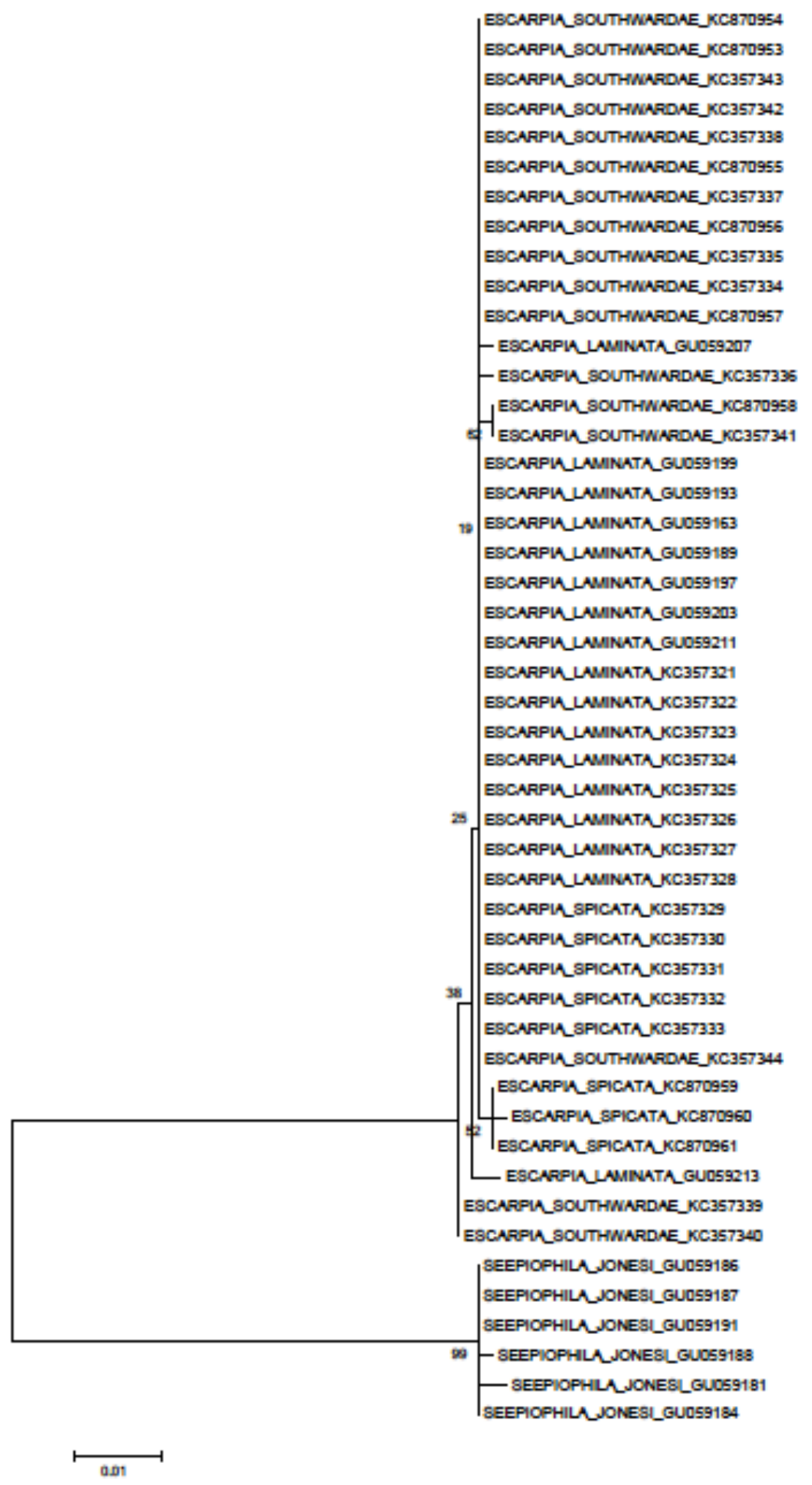


Figure S2: 16S maximum likelihood (ML) tree for 45 Escarpia and five Seepiophila, with fragment size of 435bp. 38 Escarpia sequences are newly isolated. Seepiophila jonesi is the outgroup taxon, and GenBank Accession numbers follow the species name. Bootstrap support (1000 replicates, Tamura-Nei model) is located either above or below the node. Scale is measured as number of substitutions per nucleotide site.

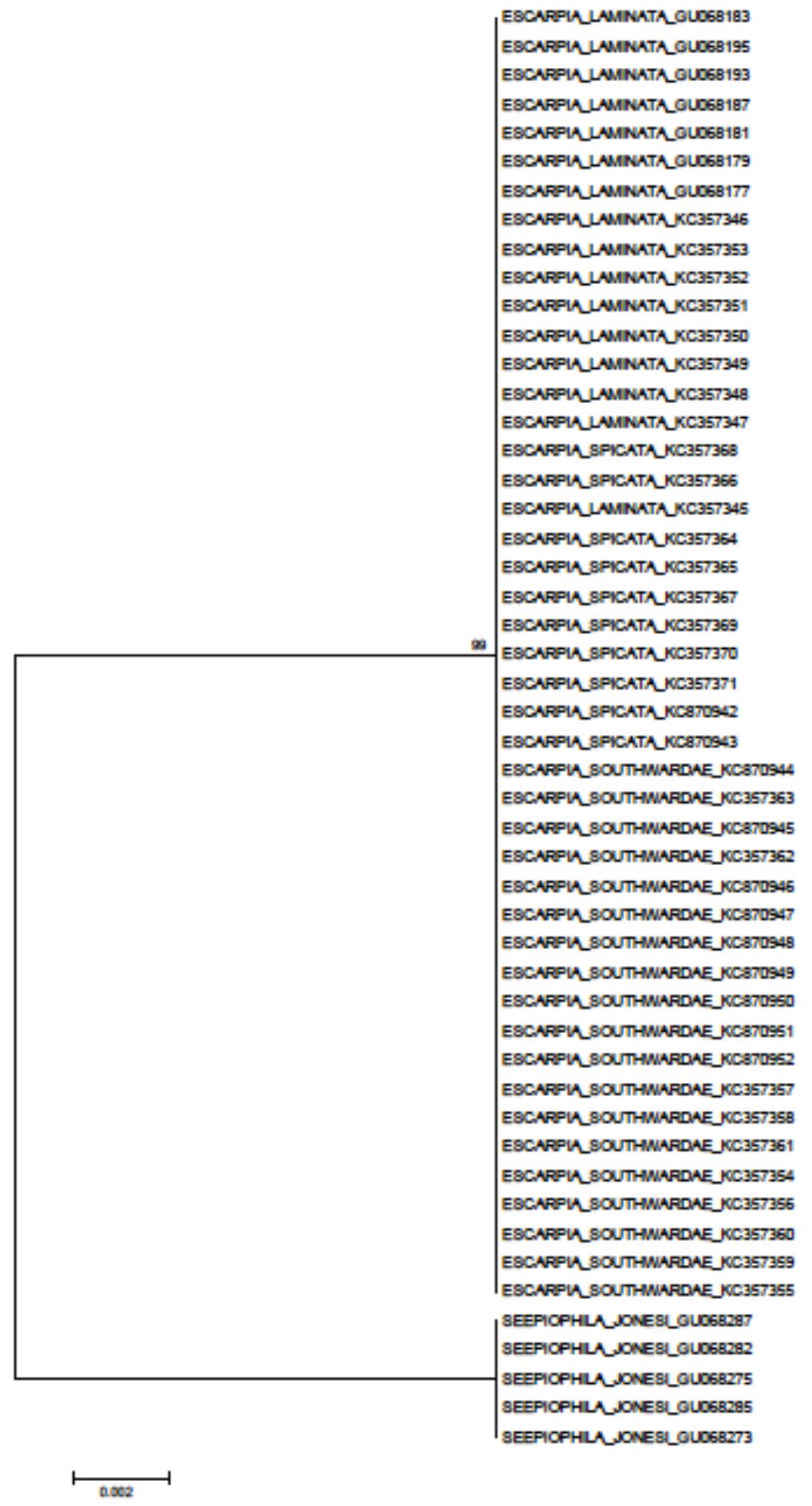


Figure S3: CYTB maximum likelihood (ML) tree for 39 Escarpia and seven Seepiophila, with fragment size of $401 \mathrm{bp}$. All sequences are newly isolated. Seepiophila jonesi is the outgroup taxon, and GenBank Accession numbers follow the species name. Bootstrap support (1000 replicates, Tamura-Nei model) is located either above or below the node. Scale is measured as number of substitutions per nucleotide site.

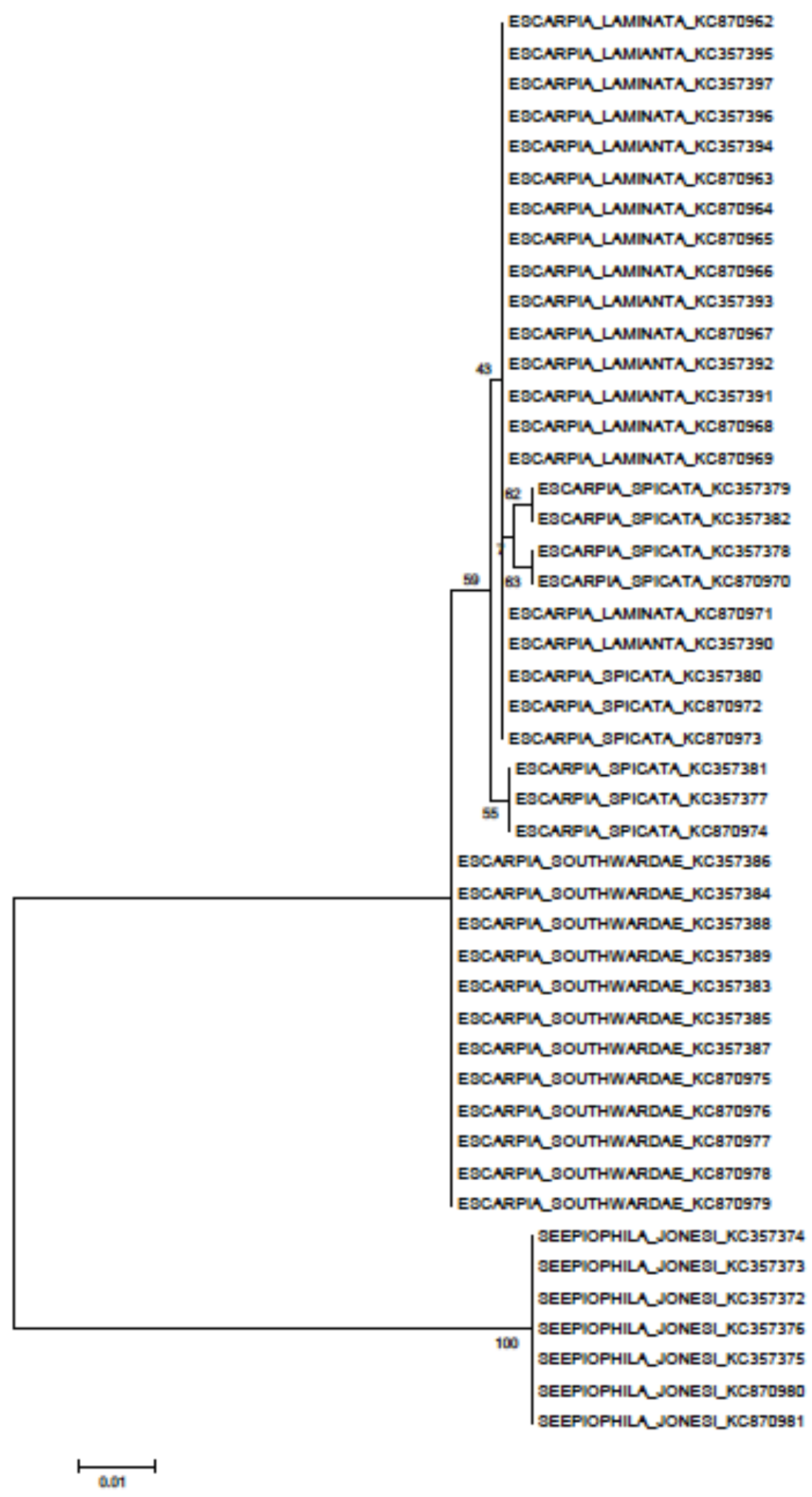


Figure S4: HbB2i maximum likelihood (ML) tree for 43 Escarpia and five Seepiophila, with fragment size of $665 \mathrm{bp}$. All sequences are new isolated. Seepiophila jonesi is the outgroup taxon, and GenBank Accession number follow the species name. Bootstrap support (1000 replicates, Tamura-Nei model) is located either above or below the node. Scale is measured as number of substitutions per nucleotide site.

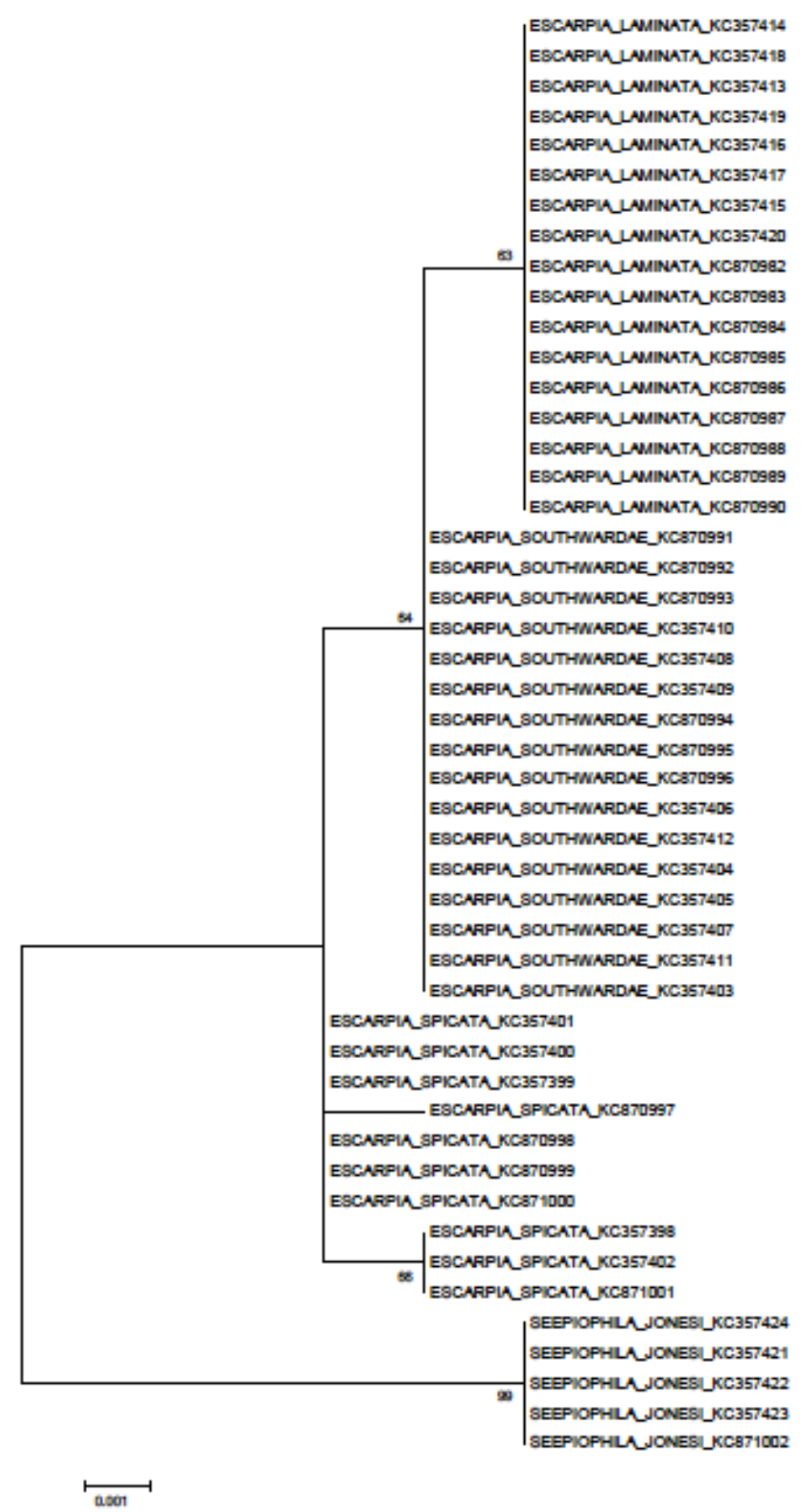


Table S1: Estimates of evolutionary divergence between species of Escarpia for three mitochondrial genes and one nuclear intron region. The numbers of base substitutions per site, averaging over all sequence pairs between groups are shown for each marker. Analyses were conducted using the Maximum Composite Likelihood model, and standard error estimates are shown above the diagonal.

\begin{tabular}{|l|l|l|l|l}
\hline Gene: COI & $\mathrm{n}=42$ & & & \\
\hline & E.laminata & E.southwardae & E.spicata & S.jonesi \\
\hline E.laminata & & 0.000 & 0.000 & 0.033 \\
\hline E.southwardae & 0.001 & & 0.000 & 0.033 \\
\hline E.spicata & 0.001 & 0.001 & & 0.033 \\
\hline S.jonesi & 0.108 & 0.108 & 0.108 &
\end{tabular}

\begin{tabular}{l|l|l|l|l|}
\hline Gene: CYTB & $\mathrm{n}=39$ & & & \\
\hline & E.laminata & E.southwardae & E.spicata & S.jonesi \\
\hline E.laminata & & 0.003 & 0.001 & 0.632 \\
\hline E.southwardae & 0.005 & & 0.003 & 0.687 \\
\hline E.spicata & 0.002 & 0.007 & & 3.246 \\
\hline S.jonesi & 0.145 & 0.127 & 0.134 &
\end{tabular}

\begin{tabular}{|l|l|l|l|l} 
Gene: $16 \mathrm{~S}$ & $\mathrm{n}=45$ & & & \\
\hline & E.laminata & E.southwardae & E.spicata & S.jonesi \\
\hline E.laminata & & 0.000 & 0.000 & 0.007 \\
\hline E.southwardae & 0.000 & & 0.000 & 0.007 \\
\hline E.spicata & 0.000 & 0.000 & & 0.007 \\
\hline S.jonesi & 0.021 & 0.021 & 0.021 & \\
\hline & & & & \\
\hline
\end{tabular}

\begin{tabular}{l|l|l|l|l|} 
Gene: $\underline{\mathrm{HbB} 2 \mathrm{i}}$ & $\mathrm{n}=43$ & & & \\
\hline & E.laminata & E.southwardae & E.spicata & S.jonesi \\
\hline E.laminata & & 0.001 & 0.002 & 0.006 \\
\hline E.southwardae & 0.002 & & 0.002 & 0.005 \\
\hline E.spicata & 0.004 & 0.002 & & 0.005 \\
\hline S.jonesi & 0.016 & 0.014 & 0.013 & \\
\hline & & & & \\
\hline
\end{tabular}


Table S2: Locations, number of individuals and GenBank IDs for all tubeworms tested in each of the four genes.

\begin{tabular}{|c|c|c|c|}
\hline Gene: $\underline{\text { COI }}$ & $n=42$ & & \\
\hline Population & Location & \# of individuals & GenBank IDs \\
\hline E. spicata & Transform Fault & 8 & $\begin{array}{l}\text { KC357329-KC357333, } \\
\text { KC870959-KC870961 }\end{array}$ \\
\hline \multirow{6}{*}{ E. laminata } & DC673 & 7 & KC357322 - КC357328 \\
\hline & AT340 & 2 & GU059203, GU059207 \\
\hline & AC601 & 3 & GU059211, KC357321 \\
\hline & WR269 & 2 & GU059199, GU059197 \\
\hline & GC852 & 1 & GU059193 \\
\hline & AC818 & 2 & GU059163, GU059189 \\
\hline \multirow{3}{*}{ E. southwardae } & Regab & 4 & $\begin{array}{l}\text { KC357334 -KC357336, } \\
\text { KC870957 }\end{array}$ \\
\hline & Worm Hole & 3 & $\begin{array}{l}\text { KC357337 -KC357343, } \\
\text { KC870955, KC870956, } \\
\text { KC870958 }\end{array}$ \\
\hline & Baboon & 10 & $\begin{array}{r}\text { KC357344, } \\
\text { KC870953 -KC870954 }\end{array}$ \\
\hline Gene: $\underline{16 S}$ & $n=45$ & & \\
\hline Population & Location & \# of individuals & GenBank IDs \\
\hline E. spicata & Transform Fault & 10 & $\begin{array}{l}\text { KC357364 - KC357371 } \\
\text { KC870942 - KC870943 }\end{array}$ \\
\hline \multirow{6}{*}{ E. laminata } & DC673 & 7 & KC357347 - KC357351 \\
\hline & AT340 & 2 & GU068183, GU068187 \\
\hline & AC601 & 2 & GU068195, GU068193 \\
\hline & WR269 & 3 & GU068181, GU068179, KC357346 \\
\hline & GC852 & 1 & GU068177 \\
\hline & MC294 & 1 & KC357345 \\
\hline \multirow{3}{*}{ E. southwardae } & Regab & 7 & $\begin{array}{c}\text { KC357354 - KC357356, } \\
\text { KC357358, KC357362, KC870944, } \\
\text { KC870949 }\end{array}$ \\
\hline & Worm Hole & 1 & KC357357 \\
\hline & Baboon & 11 & $\begin{array}{c}\text { KC357359 - KC357361, } \\
\text { KC357363, } \\
\text { KC870945 -KC870948, } \\
\text { KC870950 - KC870952 }\end{array}$ \\
\hline
\end{tabular}

\begin{tabular}{|c|c|c|c|}
\hline Gene: $\underline{\text { CYTB }}$ & $\mathbf{n}=\mathbf{3 9}$ & & \\
\hline Population & Location & \# of individuals & GenBank IDs \\
\hline E. spicata & Transform Fault & 10 & $\begin{array}{l}\text { KC357377 - KC357382 } \\
\text { KC870970, KC870972, } \\
\text { KC870974 }\end{array}$ \\
\hline \multirow{6}{*}{ E. laminata } & DC673 & 8 & $\begin{array}{l}\text { KC357384 - KC357387 } \\
\text { KC357391 - KC357393 } \\
\end{array}$ \\
\hline & AC601 & 2 & KC870968-KC870969 \\
\hline & WR269 & 2 & KC870964, KC870967 \\
\hline & GC852 & 2 & KC870963, KC870965 \\
\hline & AC 818 & 2 & KC870966, KC870971 \\
\hline & MC294 & 1 & KC870962, KC870973 \\
\hline \multirow{3}{*}{ E. southwardae } & Regab & 5 & KC357385 - KC357389 \\
\hline & Worm Hole & 4 & $\begin{array}{r}\text { KC357384, } \\
\text { KC870975-KC870977 }\end{array}$ \\
\hline & Baboon & 3 & $\begin{array}{r}\text { KC357383, } \\
\text { KC870978-KC870979 }\end{array}$ \\
\hline Gene: $\underline{\mathrm{HbB} 2 \mathrm{i}}$ & $n=43$ & & \\
\hline Population & Location & \# of individuals & GenBank IDs \\
\hline E. spicata & Transform Fault & 10 & $\begin{array}{c}\text { KC57398 - KC57402, KC870997- } \\
\text { KC871001 } \\
\end{array}$ \\
\hline \multirow{6}{*}{ E. laminata } & DC673 & 8 & KC57413 - KC57420 \\
\hline & AT340 & 2 & KC870983, KC870984 \\
\hline & AC601 & 2 & KC870985, KC870986 \\
\hline & WR269 & 1 & KC870987 \\
\hline & AC818 & 1 & KC870989 \\
\hline & MC294 & 3 & КС870982, КС870990 \\
\hline \multirow{3}{*}{ E. southwardae } & Regab & 5 & KC57408 - KC57412 \\
\hline & Worm Hole & 3 & $\begin{array}{c}\text { KC57403 - KC57407, KC870991- } \\
\text { KC870993 }\end{array}$ \\
\hline & Baboon & 8 & KC870994 - KC870997 \\
\hline
\end{tabular}


Table S3: Summary statistics for Tajima's D test of neutrality organized by gene and species. $S$ is number of sites with substitutions; $P i$ is the mean number of pairwise differences. Distance method used is pairwise difference, no Gamma correction, indels not taken into account.

\begin{tabular}{|c|c|c|c|c|c|c|}
\hline Gene: COI & E_laminata & E.southwardae & E.spicata & S.jonesi & Mean & s.d. \\
\hline Sample Size & 8 & 12 & 5 & 4 & 7.250 & 3.594 \\
\hline S & 1 & 3 & 0 & 1 & 1.250 & 1.260 \\
\hline Pi & 1.071 & 0.636 & 0.000 & 40.000 & 10.426 & 19.720 \\
\hline Tajima's D & 1.166 & -1.180 & 0.000 & 1.633 & 0.405 & 1.259 \\
\hline p-value & 0.926 & 0.108 & 1.000 & 0.960 & 0.748 & 0.428 \\
\hline Gene: 16S & E_laminata & E.southwardae & E.spicata & S.jonesi & Mean & s.d. \\
\hline Sample Size & 18 & 20 & 16 & 10 & 16 & 4.320 \\
\hline S & 0 & 1 & 0 & 0 & 0.250 & 0.500 \\
\hline Pi & 0.000 & 0.100 & 0.000 & 0.000 & 0.0250 & 0.0500 \\
\hline Tajima's D & 0.000 & -1.164 & 0.000 & 0.000 & -0.291 & -0.582 \\
\hline p-value & 1.000 & 0.144 & 1.000 & 1.000 & 0.786 & 0.428 \\
\hline Gene: CYTB & E_laminata & E.southwardae & E.spicata & S.jonesi & Mean & s.d. \\
\hline Sample Size & 8 & 7 & 6 & 5 & 6.500 & 1.291 \\
\hline S & 0 & 0 & 3 & 0 & 0.750 & 1.500 \\
\hline Pi & 0.000 & 0.000 & 1.400 & 0.000 & 0.350 & 0.700 \\
\hline Tajima's D & 0.000 & 0.000 & 0.338 & 0.000 & 0.084 & 0.169 \\
\hline p-value & 1.000 & 1.000 & 0.655 & 1.000 & 0.913 & 0.175 \\
\hline Gene: hbB2i & E_laminata & E.southwardae & E.spicata & S.jonesi & Mean & s.d. \\
\hline Sample Size & 16 & 20 & 10 & 8 & 13.5 & 5.507 \\
\hline S & 0 & 0 & 2 & 0 & 0.500 & 1.000 \\
\hline Pi & 0.000 & 0.000 & 1.088 & 0.000 & 0.435 & 0.871 \\
\hline Tajima's D & 0.000 & 0.000 & 1.742 & 0.000 & 0.435 & 0.871 \\
\hline p-value & 1.000 & 1.000 & 0.977 & 1.000 & 0.994 & 0.011 \\
\hline
\end{tabular}


Table S4: Summary statistics for nine microsatellite loci amplified in three described Escarpia species

\begin{tabular}{|c|c|c|c|c|c|c|c|c|c|c|c|}
\hline \multicolumn{2}{|l|}{ Population } & EL454_2 & EL454_5 & EL454_9 & EL454_21 & EL454_25 & EL454_52 & EL454_64 & EL454_70 & EL454_71 & Mean \\
\hline E. spicata & $N_{A}$ & 9 & 7 & 7 & 6 & 8 & 9 & 12 & 11 & 3 & 8 \\
\hline$N=20$ & $H_{O}$ & 0.900 & 0.700 & 0.842 & 0.300 & 0.850 & 0.667 & 0.684 & 0.667 & 0.600 & 0.690 \\
\hline & $H_{E}$ & 0.830 & 0.765 & 0.816 & 0.680 & 0.827 & 0.860 & 0.900 & 0.871 & 0.476 & 0.780 \\
\hline & $F_{I S}$ & -0.083 & 0.085 & 0.040 & $* 0.560$ & -0.028 & 0.317 & 0.282 & 0.325 & 0.308 & 0.194 \\
\hline E. laminata & $N_{A}$ & 12 & 15 & 19 & 9 & 12 & 16 & 14 & 18 & 4 & 13 \\
\hline$N=129$ & $H_{O}$ & 0.700 & 0.730 & 0.631 & 0.752 & 0.610 & 0.821 & 0.853 & 0.872 & 0.162 & 0.681 \\
\hline & $H_{E}$ & 0.725 & 0.735 & 0.920 & 0.800 & 0.593 & 0.886 & 0,862 & 0.915 & 0.342 & 0.753 \\
\hline & $F_{I S}$ & 0.039 & 0.010 & $* 0.396$ & 0.060 & -0.009 & 0.072 & 0.067 & 0.081 & 0.751 & 0.149 \\
\hline E. southwardae & $N_{A}$ & 15 & 11 & 10 & 9 & 7 & 18 & 17 & 10 & 4 & 12 \\
\hline$N=80$ & $H_{O}$ & 0.825 & 0.862 & 0.605 & 0.710 & 0.740 & 0.873 & 0.720 & 0.712 & 0.276 & 0.702 \\
\hline & $H_{E}$ & 0.870 & 0.876 & 0.874 & 0.780 & 0.741 & 0.906 & 0.746 & 0.726 & 0.262 & 0.753 \\
\hline & $F_{I S}$ & 0.049 & 0.015 & $* 0.350$ & 0.154 & 0.005 & 0.051 & 0.127 & 0.019 & 0.210 & 0.104 \\
\hline
\end{tabular}

Abbreviations: number of alleles observed per locus $\left(N_{A}\right)$, observed $\left(H_{O}\right)$ and expected $\left(H_{E}\right)$ heterozygosity, Wright's Inbreeding Coefficient $\left(F_{I S}\right)$.

Negative values scaled to zero; * bold asterisk indicates a significant difference after applying FDR correction $=0.01$ 
Table S5: Pairwise genetic differentiation matrix. F ST $_{\text {T }}$ values (below diagonal) and Jost's $D$ (above diagonal, calculated in GenoDive) between the three described species of Escarpia; species are significantly different at $\mathrm{p}=0.001$. Both measures quantify genetic diversity differently and both suffer from limitations, and therefore it has been suggested to use both measures in concert (Meirmans and Hedrick, 2011). F ST $_{\text {measures the level }}$ of heterozygosity, while Jost's $D$ quantifies genetic diversity in terms of effective number of alleles (Jost, 2008; Ryman and Leimar, 2009. In this case, calculations of both metrics show similar relationships and patterns of differentiation between groups.

\begin{tabular}{|c|c|c|c|}
\hline & Escarpia laminata & Escarpia spicata & Escarpia southwardae \\
\hline Escarpia laminata & --- & 0.422 & 0.455 \\
\hline Escarpia spicata & 0.115 & --- & 0.501 \\
\hline Escarpia southwardae & 0.130 & 0.134 & --- \\
\hline
\end{tabular}

Table S6: Primers used in this study

\begin{tabular}{|c|c|c|c|c|}
\hline Gene & Primers & Forward $\left(5^{\prime}-3^{\prime}\right)$ & Reverse (5' - 3') & Reference \\
\hline $\mathrm{COI}$ & $\begin{array}{l}\mathrm{LCO} \\
\mathrm{HCO}\end{array}$ & $\begin{array}{l}\text { GGT CAA CAA ATC ATA AAG } \\
\text { ATA TT GG }\end{array}$ & $\begin{array}{l}\text { TAA ACT TCA GGG TGA } \\
\text { CCA AAA AA TCA }\end{array}$ & Folmer et al., 1994 \\
\hline $16 \mathrm{~S}$ & $\begin{array}{l}16 \mathrm{sar} \\
16 \mathrm{sbr}\end{array}$ & $\begin{array}{l}\text { CGC CTG TTT ATC AAA AAA } \\
\text { CAT }\end{array}$ & $\begin{array}{l}\text { ACG TGA TCT GAG TTC AGA } \\
\text { CCG G }\end{array}$ & Palumbi, 1996 \\
\hline Cytb & $\begin{array}{l}\text { CytbF } \\
\text { CytbR }\end{array}$ & $\begin{array}{l}\text { GGW TAY GTW YTW CCW } \\
\text { TGR GGW CAR AT } \\
\end{array}$ & $\begin{array}{l}\text { GCR TAW GCR AAW ARR } \\
\text { AAR TAY CAY TCW GG }\end{array}$ & $\begin{array}{l}\text { Boore and Brown, } \\
2000\end{array}$ \\
\hline CYTB & $\begin{array}{l}\text { CYTBF } \\
\text { CYTBR }\end{array}$ & $\begin{array}{l}\text { AAA TCC TCC CTC ACA GTC } \\
\text { ATT }\end{array}$ & $\begin{array}{l}\text { CCA GCC CCG ATG AAT CTT } \\
\text { TC }\end{array}$ & This study \\
\hline $\begin{array}{l}\text { hbB2 intron } \\
\text { (Riftia/Ridgeia) }\end{array}$ & $\begin{array}{l}\mathrm{hbB} 2 \mathrm{~F} \\
\mathrm{hbB} 2 \mathrm{R}\end{array}$ & $\begin{array}{l}\text { CAG TTC ACT GGA CGT CGT } \\
\text { CT }\end{array}$ & $\begin{array}{l}\text { CTA TGC AGG CAG ACC } \\
\text { ATC G }\end{array}$ & $\begin{array}{l}\text { S. Carney, } 2005 \\
\text { (dissertation) }\end{array}$ \\
\hline hbB2i (Escarpia) & $\begin{array}{l}\text { hbB2i_F } \\
\text { hbB2i_R }\end{array}$ & $\begin{array}{l}\text { TCC ATC GCC CCA GGC TGT } \\
\text { CTT C }\end{array}$ & $\begin{array}{l}\text { GCC TTG AAT TCG TTG CTG } \\
\text { TT }\end{array}$ & This study \\
\hline
\end{tabular}


Table S7: Summary statistics for eleven microsatellite loci amplified in eight populations of Escarpia laminata (GoM).

\begin{tabular}{|c|c|c|c|c|c|c|c|c|c|c|c|c|c|}
\hline \multicolumn{2}{|c|}{ Population } & EL454_2 & EL454_5 & EL454_6 & EL454_9 & EL454_21 & EL454_25 & EL454_52 & EL454_54 & EL454_67 & EL454_70 & EL454_71 & Mean \\
\hline AC601 & $N_{A}$ & 6 & 8 & 3 & 12 & 5 & 5 & 11 & 11 & 2 & 13 & 2 & 7.3 \\
\hline \multirow[t]{3}{*}{$N=12$} & $H_{O}$ & 0.583 & 0.833 & 0.454 & 0.750 & 0.750 & 0.420 & 0.750 & 0.920 & 0.111 & 0.920 & 0.000 & 0.615 \\
\hline & $H_{E}$ & 0.710 & 0.793 & 0.627 & 0.931 & 0.822 & 0.492 & 0.884 & 0.891 & 0.111 & 0.920 & 0.160 & 0.686 \\
\hline & $F_{I S}$ & 0.179 & -0.050 & 0.392 & 0.195 & 0.088 & 0.154 & 0.152 & -0.028 & 0.816 & 0.000 & 1.000 & 0.171 \\
\hline AC818 & $N_{A}$ & 5 & 5 & 3 & 8 & 6 & 4 & 9 & 6 & 2 & 4 & 2 & 5.1 \\
\hline \multirow[t]{3}{*}{$N=8$} & $H_{O}$ & 0.625 & 0.750 & 0.500 & 0.750 & 0.625 & 0.625 & 0.750 & 0.500 & 0.375 & 0.750 & 0.143 & 0.602 \\
\hline & $H_{E}$ & 0.742 & 0.792 & 0.425 & 0.883 & 0.820 & 0.575 & 0.883 & 0.818 & 0.325 & 0.708 & 0.494 & 0.693 \\
\hline & $F_{I S}$ & 0.157 & 0.053 & -0.176 & 0.151 & 0.235 & -0 & 0.151 & 0.559 & -0.154 & -0.059 & 0.795 & 0.191 \\
\hline WR269 & $N_{A}$ & 5 & 6 & 4 & 8 & 4 & 4 & 9 & 6 & 2 & 10 & 3 & 5.7 \\
\hline \multirow[t]{3}{*}{$N=7$} & $H_{O}$ & 0.571 & 0.857 & 0.333 & 1.000 & 0.714 & 1.000 & 0.571 & 0.800 & 0.285 & 1.000 & 0.167 & 0.658 \\
\hline & $H_{E}$ & 0.593 & 0.791 & 0.454 & 0.924 & 0.703 & 0.692 & 0.912 & 0.890 & 0.264 & 0.945 & 0.621 & 0.725 \\
\hline & $F_{I S}$ & 0.037 & -0.083 & 0.519 & 0.082 & 0.016 & -0.444 & 0.373 & 0.350 & -0.083 & -0.058 & 0.800 & 0.182 \\
\hline GC852 & $N_{A}$ & 7 & 8 & 3 & 6 & 7 & 5 & 9 & 10 & 3 & 10 & 3 & 6.7 \\
\hline \multirow[t]{3}{*}{$N=11$} & $H_{O}$ & 0.545 & 0.818 & 0.400 & 0.500 & 0.730 & 0.600 & 1.000 & 0.700 & 0.222 & 1.000 & 0.100 & 0.626 \\
\hline & $H_{E}$ & 0.714 & 0.814 & 0.360 & 0.803 & 0.840 & 0.600 & 0.900 & 0.890 & 0.216 & 0.895 & 0.280 & 0.682 \\
\hline & $F_{I S}$ & 0.152 & 0.062 & 0.229 & 0.247 & 0.067 & 0.160 & -0.009 & 0.160 & 0.171 & 0.171 & 0.250 & 0.151 \\
\hline AT340 & $N_{A}$ & 6 & 7 & 5 & 11 & 5 & 4 & 6 & 8 & 4 & 10 & 2 & 6.6 \\
\hline \multirow[t]{3}{*}{$N=11$} & $H_{O}$ & 0.730 & 0.636 & 0.545 & 0.890 & 0.818 & 0.636 & 0.730 & 0.800 & 0.454 & 0.730 & 0.300 & 0.680 \\
\hline & $H_{E}$ & 0.684 & 0.805 & 0.467 & 0.930 & 0.775 & 0.671 & 0.818 & 0.895 & 0.400 & 0.880 & 0.395 & 0.720 \\
\hline & $F_{I S}$ & -0.018 & 0.071 & 0.067 & 0.071 & 0.087 & 0.164 & 0.087 & 0.079 & 0.152 & 0.25 & -0.004 & 0.083 \\
\hline MC294 & $N_{A}$ & 6 & 6 & 1 & 8 & 7 & 6 & 8 & 7 & 3 & 8 & 3 & 6.4 \\
\hline \multirow[t]{3}{*}{$N=8$} & $H_{O}$ & 0.875 & 0.750 & --- & 0.500 & 0.875 & 0.750 & 0.875 & 0.625 & 0.428 & 0.857 & 0.125 & 0.670 \\
\hline & $H_{E}$ & 0.833 & 0.620 & --- & 0.910 & 0.883 & 0.683 & 0.920 & 0.883 & 0.384 & 0.890 & 0.610 & 0.773 \\
\hline & $F_{I S}$ & -0.050 & -0.216 & 1 & 0.450 & 0.009 & -0.098 & 0.045 & 0.292 & 0.286 & 0.174 & 0.795 & 0.179 \\
\hline DC673 & $N_{A}$ & 11 & 11 & 7 & 14 & 8 & 8 & 11 & 17 & 3 & 18 & 3 & 10.8 \\
\hline \multirow[t]{3}{*}{$N=42$} & $H_{O}$ & 0.833 & 0.762 & 0.440 & 0.641 & 0.714 & 0.571 & 0.890 & 0.750 & 0.187 & 0.880 & 0.286 & 0.645 \\
\hline & $H_{E}$ & 0.736 & 0.747 & 0.520 & 0.920 & 0.791 & 0.600 & 0.880 & 0.902 & 0.180 & 0.920 & 0.304 & 0.702 \\
\hline & $F_{I S}$ & 0.244 & 0.246 & 0.133 & $* 0.151$ & 0.127 & 0.223 & 0.202 & 0.169 & 0.197 & 0.158 & 0.105 & 0.186 \\
\hline WFE & $N_{A}$ & 9 & 15 & 6 & 13 & 7 & 8 & 12 & 13 & 3 & 17 & 3 & 9.7 \\
\hline \multirow[t]{3}{*}{$N=30$} & $H_{O}$ & 0.600 & 0.600 & 0.433 & 0.423 & 0.800 & 0.600 & 0.800 & 0.821 & 0.520 & 0.862 & 0.083 & 0.612 \\
\hline & $H_{E}$ & 0.724 & 0.639 & 0.450 & 0.910 & 0.821 & 0.580 & 0.883 & 0.910 & 0.427 & 0.930 & 0.230 & 0.702 \\
\hline & $F_{I S}$ & 0.248 & 0.249 & 0.189 & $* 0.146$ & 0.283 & 0.117 & 0.213 & 0.119 & 0.177 & 0.113 & 0.324 & 0.194 \\
\hline
\end{tabular}

Abbreviations: number of alleles observed per locus $\left(N_{A}\right)$, observed $\left(H_{O}\right)$ and expected $\left(H_{E}\right)$ heterozygosity, Wright's Inbreeding Coefficient $\left(F_{I S}\right)$.

* bold asterisk indicates a significant difference after applying FDR correction $=0.01$ 
Table S8: Pairwise genetic differentiation matrix. $\mathrm{F}_{\mathrm{ST}}$ values (below diagonal) and Jost's $D$ (above diagonal) between the eight populations of Escarpia laminata $(\mathrm{GoM})$; populations are ordered from west to east and are not significantly different ( $\mathrm{p}>0.05)$. Both measures quantify genetic diversity differently and both suffer from limitations, and therefore it has been suggested to use both

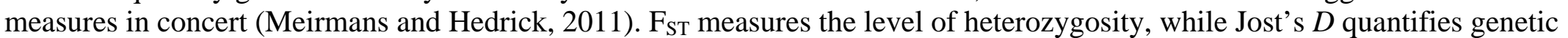
diversity in terms of effective number of alleles (Jost, 2008; Ryman and Leimar, 2009. In this case, calculations of both metrics show similar relationships and patterns of differentiation between groups.

\begin{tabular}{|c|c|c|c|c|c|c|c|c|}
\hline & AC601 & AC818 & WR269 & GC852 & AT340 & MC388 & DC673 & WFE \\
\hline AC601 & --- & 0.054 & 0.019 & 0.030 & 0.017 & 0.079 & 0.001 & 0.029 \\
\hline AC818 & 0.014 & --- & 0.000 & 0.058 & 0.032 & 0.045 & 0.057 & 0.086 \\
\hline WR269 & 0.007 & 0.007 & --- & 0.000 & 0.000 & 0.000 & 0.000 & 0.018 \\
\hline GC852 & 0.016 & 0.006 & 0.000 & --- & 0.009 & 0.048 & 0.003 & 0.014 \\
\hline AT340 & 0.020 & 0.018 & 0.000 & 0.000 & -- & 0.010 & 0.005 & 0.019 \\
\hline MC388 & 0.048 & 0.036 & 0.027 & 0.024 & 0.021 & --- & 0.037 & 0.020 \\
\hline DC673 & 0.007 & 0.016 & 0.000 & 0.000 & 0.003 & 0.020 & --- & 0.000 \\
\hline WFE & 0.018 & 0.024 & 0.000 & 0.005 & 0.011 & 0.007 & 0.000 & --- \\
\hline
\end{tabular}


Table S9: Summary statistics for sixteen microsatellite loci amplified in three populations of Escarpia southwardae (WACS).

\begin{tabular}{|c|c|c|c|c|c|c|c|c|c|c|c|c|}
\hline \multirow{3}{*}{ Locus } & \multicolumn{12}{|c|}{ Population } \\
\hline & \multicolumn{4}{|c|}{$\begin{array}{c}\text { Worm Hole } \\
\quad(n=25)\end{array}$} & \multicolumn{4}{|c|}{$\begin{array}{l}\text { Baboon } \\
(n=27)\end{array}$} & \multicolumn{4}{|c|}{$\begin{array}{c}\text { Regab } \\
(n=28)\end{array}$} \\
\hline & $N_{A}$ & $H_{O}$ & $H_{E}$ & $F_{I S}$ & $N_{A}$ & $H_{O}$ & $H_{E}$ & $F_{I S}$ & $N_{A}$ & $H_{O}$ & $H_{E}$ & $F_{I S}$ \\
\hline ES454_8 & 6 & 0.480 & 0.601 & 0.201 & 6 & 0.555 & 0.606 & 0.154 & 6 & 0.555 & 0.556 & 0.001 \\
\hline ES454_10 & 11 & 0.916 & 0.845 & -0.027 & 15 & 0.821 & 0.848 & 0.031 & 13 & 0.815 & 0.877 & 0.072 \\
\hline ES454_13 & 9 & 0.400 & 0.420 & 0.049 & 7 & 0.444 & 0.422 & 0.073 & 8 & 0.423 & 0.408 & 0.086 \\
\hline ES454_25 & 18 & 0.880 & 0.938 & 0.063 & 15 & 0.926 & 0.902 & 0.017 & 16 & 0.923 & 0.924 & 0.043 \\
\hline ES454_28 & 7 & 0.791 & 0.791 & 0.058 & 7 & 0.785 & 0.777 & -0.010 & 8 & 0.777 & 0.773 & -0.006 \\
\hline ES454_31 & 19 & 0.800 & 0.918 & 0.129 & 14 & 0.852 & 0.901 & 0.095 & 11 & 0.730 & 0.872 & 0.201 \\
\hline ES454_32 & 4 & 0.160 & 0.405 & $* 0.606$ & 2 & 0.035 & 0.035 & 0.000 & 5 & 0.296 & 0.273 & -0.084 \\
\hline ES454_34 & 6 & 0.791 & 0.720 & -0.025 & 5 & 0.714 & 0.732 & 0.025 & 7 & 0.777 & 0.737 & -0.054 \\
\hline ES454_44 & 5 & 0.680 & 0.627 & -0.083 & 5 & 0.740 & 0.643 & -0.070 & 6 & 0.654 & 0.670 & 0.093 \\
\hline ES454_45 & 10 & 0.200 & 0.452 & $* 0.558$ & 14 & 0.296 & 0.660 & *0.582 & 11 & 0.192 & 0.466 & 0.633 \\
\hline ES454_50 & 11 & 0.904 & 0.859 & 0.135 & 7 & 0.571 & 0.685 & 0.167 & 9 & 0.880 & 0.820 & 0.032 \\
\hline ES454_57 & 9 & 0.840 & 0.841 & 0.001 & 13 & 0.852 & 0.880 & 0.075 & 10 & 0.815 & 0.852 & 0.044 \\
\hline ES454_60 & 9 & 0.720 & 0.624 & -0.153 & 6 & 0.481 & 0.441 & 0.032 & 7 & 0.407 & 0.420 & 0.028 \\
\hline ES454_64 & 6 & 0.682 & 0.644 & 0.159 & 6 & 0.428 & 0.443 & 0.032 & 4 & 0.308 & 0.337 & 0.230 \\
\hline ES454_71 & 16 & 0.913 & 0.902 & 0.080 & 16 & 0.958 & 0.861 & 0.066 & 15 & 0.640 & 0.846 & 0.314 \\
\hline ES454_95 & 6 & 0.800 & 0.754 & -0.061 & 7 & 0.714 & 0.784 & 1.00 & 5 & 0.704 & 0.708 & 0.006 \\
\hline Mean & 9.4 & 0.685 & 0.709 & 0.081 & 9.2 & 0.636 & 0.664 & 0.149 & 8.7 & 0.618 & 0.658 & 0.100 \\
\hline
\end{tabular}

Abbreviations: number of alleles observed per locus $\left(N_{A}\right)$, observed $\left(H_{O}\right)$ and expected $\left(H_{E}\right)$ heterozygosity, Wright's Inbreeding Coefficient $\left(F_{I S}\right) . *$ bold asterisk indicates a significant difference after applying FDR correction $=0.01$ 
Table S10: Pairwise genetic differentiation matrix. FST values (below diagonal) and Jost's $D$ (above diagonal) between the three populations of Escarpia southwardae. Populations are not significantly different at $\mathrm{p}>0.05$. Both measures quantify genetic diversity differently and both suffer from limitations, and therefore it has been suggested to use both measures in concert (Meirmans and Hedrick, 2011). F $_{\mathrm{ST}}$ measures the level of heterozygosity, while Jost's $D$ quantifies genetic diversity in terms of effective number of alleles (Jost, 2008; Ryman and Leimar, 2009. In this case, calculations of both metrics show similar relationships and patterns of differentiation between groups.

\begin{tabular}{|c|c|c|c|}
\hline & Worm Hole & Baboon & Regab \\
\hline Worm Hole & --- & 0.014 & 0.008 \\
\hline Baboon & 0.007 & --- & 0.001 \\
\hline Regab & 0.004 & 0.000 & --- \\
\hline
\end{tabular}


Table S11: BOTTLENECK summary statistics for E. laminata sites. T.P.M: Two Phase Model (Wilcoxon test, 1000 replicates). N: sample size, ko: observed number of alleles, He: Hardy-Weinberg heterozygosity, Heq: expected heterozygosity measured, S.D: standard deviation of mutation drift equilibrium distribution of heterozygosity; Prob: probability of obtaining the measured He in a sample from an equilibrium population (Piry et al., 1999).

Population: AC601

Under the T.P.M.

$\begin{array}{cccccccc}\text { locus } & \mathrm{N} & \text { ko } & \text { He } & \text { Heq } & \text { S.D. } & \text { DH/sd } & \text { Prob } \\ \text { EL454_2 } & 24 & 6 & 0.71 & 0.759 & 0.067 & -0.736 & 0.185 \\ \text { EL454_5 } & 24 & 8 & 0.793 & 0.84 & 0.042 & -1.098 & 0.126 \\ \text { EL454_6 } & 22 & 3 & 0.628 & 0.503 & 0.138 & 0.899 & 0.188 \\ \text { EL454_21 } & 24 & 5 & 0.822 & 0.698 & 0.085 & 1.46 & 0.007 \\ \text { EL454_25 } & 24 & 5 & 0.493 & 0.7 & 0.081 & -2.559 & 0.031 \\ \text { EL454_52 } & 24 & 11 & 0.884 & 0.904 & 0.022 & -0.918 & 0.16 \\ \text { EL454_70 } & 24 & 13 & 0.917 & 0.93 & 0.017 & -0.789 & 0.167 \\ \text { EL454_54 } & 24 & 11 & 0.891 & 0.905 & 0.023 & -0.578 & 0.231 \\ \text { EL454_67 } & 18 & 2 & 0.111 & 0.319 & 0.153 & -1.358 & 0.237 \\ \text { EL454_71 } & 24 & 2 & 0.159 & 0.288 & 0.155 & -0.831 & 0.347 \\ \text { EL454_9 } & 24 & 12 & 0.931 & 0.916 & 0.025 & 0.596 & 0.286\end{array}$

\section{Population: AC818}

Under the T.P.M.

$\begin{array}{cccccccc}\text { locus } & \mathrm{n} & \text { ko } & \text { He } & \text { Heq } & \text { S.D. } & \text { DH/sd } & \text { Prob } \\ \text { EL454_2 } & 16 & 5 & 0.742 & 0.743 & 0.072 & -0.023 & 0.392 \\ \text { EL454_5 } & 16 & 5 & 0.792 & 0.741 & 0.068 & 0.739 & 0.297 \\ \text { EL454_6 } & 16 & 3 & 0.425 & 0.53 & 0.124 & -0.848 & 0.232 \\ \text { EL454_21 } & 16 & 6 & 0.817 & 0.801 & 0.053 & 0.293 & 0.51\end{array}$




$\begin{array}{llllllll}\text { EL454_25 } & 16 & 4 & 0.575 & 0.649 & 0.098 & -0.762 & 0.202 \\ \text { EL454_52 } & 16 & 9 & 0.883 & 0.905 & 0.023 & -0.946 & 0.169 \\ \text { EL454_70 } & 16 & 4 & 0.708 & 0.661 & 0.091 & 0.52 & 0.385 \\ \text { EL454_54 } & 12 & 6 & 0.818 & 0.842 & 0.04 & -0.588 & 0.314 \\ \text { EL454_67 } & 16 & 2 & 0.325 & 0.316 & 0.151 & 0.061 & 0.556 \\ \text { EL454_71 } & 14 & 2 & 0.495 & 0.324 & 0.15 & 1.133 & 0.259 \\ \text { EL454_9 } & 16 & 8 & 0.883 & 0.879 & 0.03 & 0.146 & 0.581\end{array}$

Population: WR269

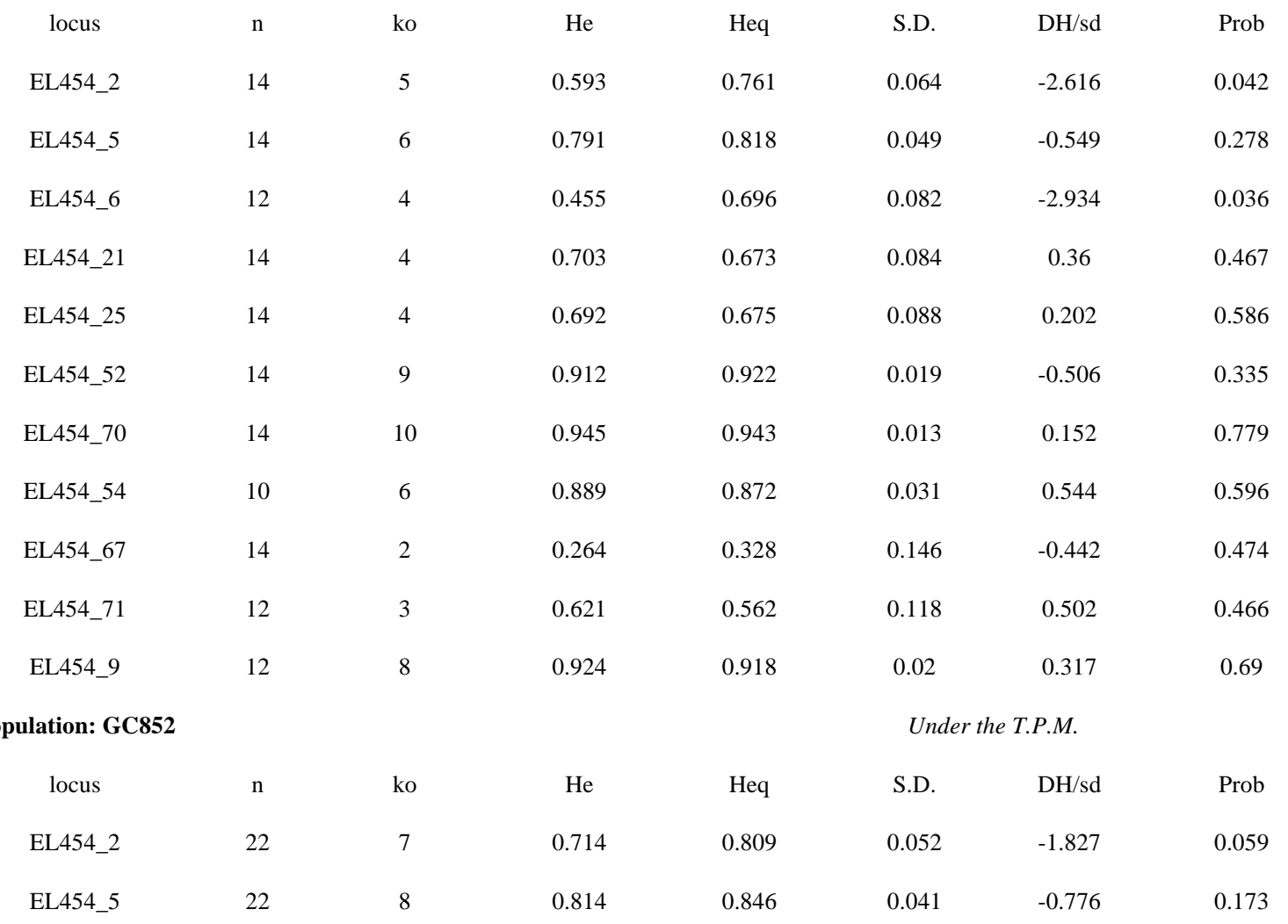




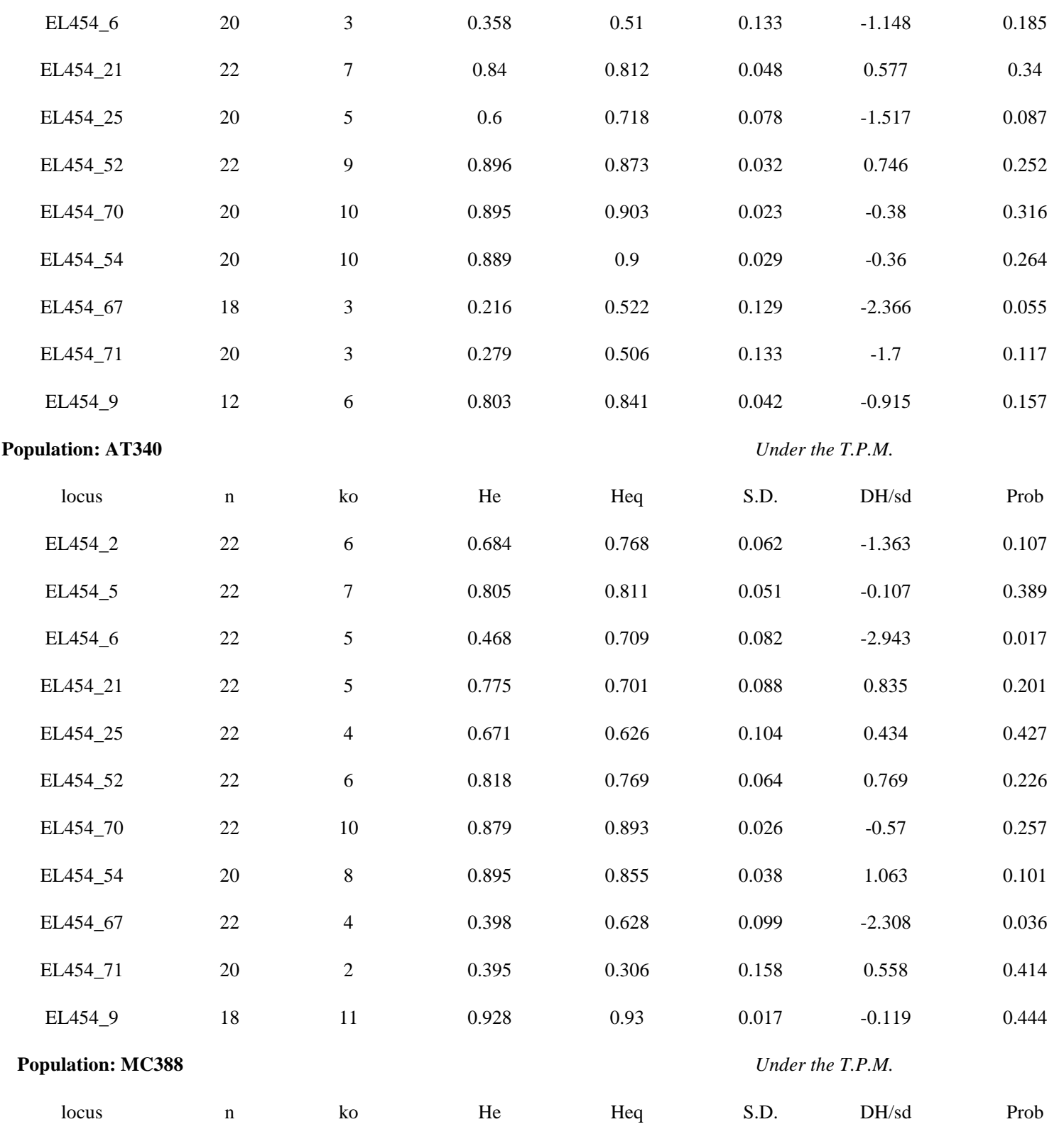




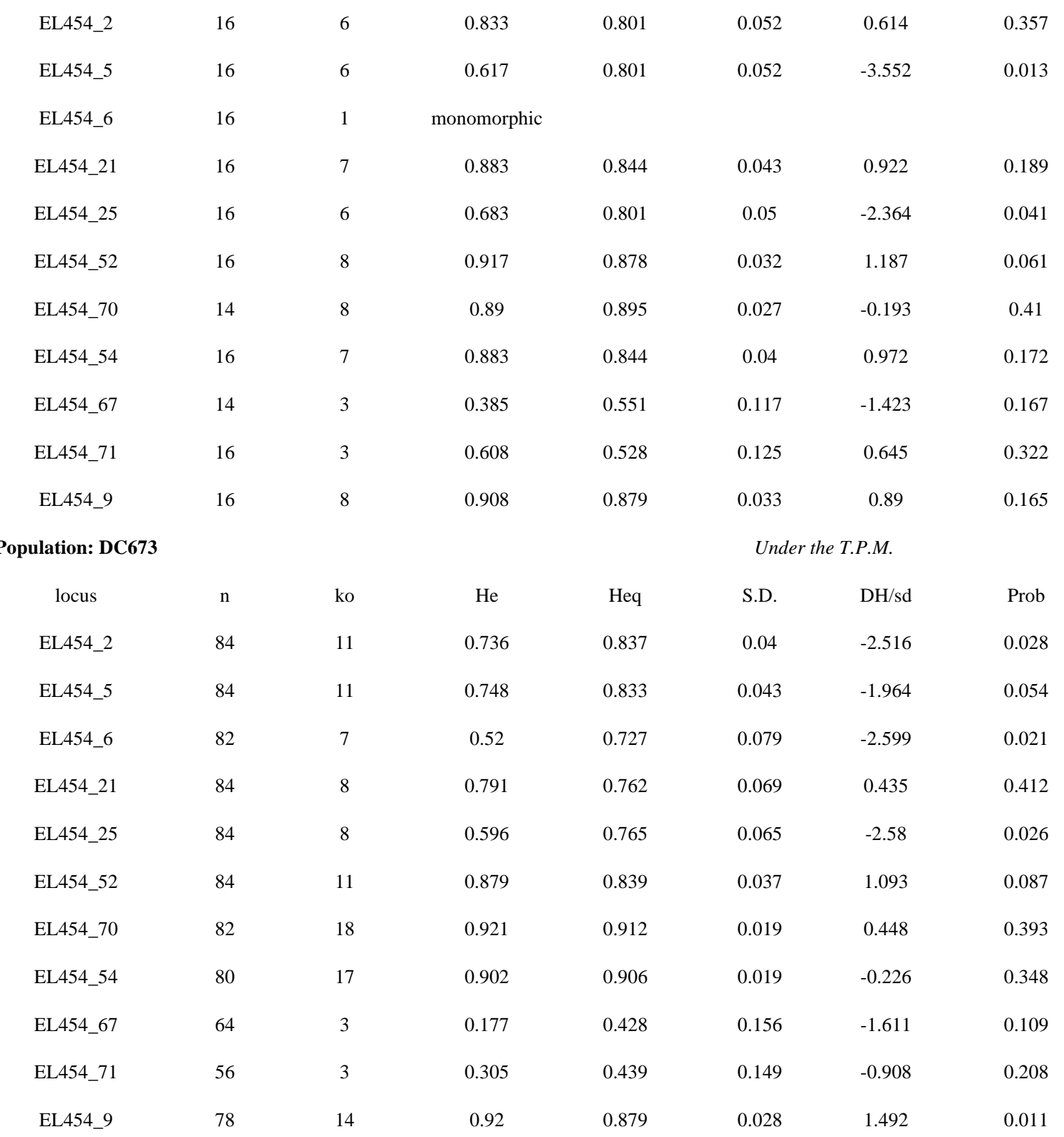


Population: WFE

Under the T.P.M.

$\begin{array}{cccccccc}\text { locus } & \mathrm{n} & \mathrm{ko} & \mathrm{He} & \mathrm{Heq} & \text { S.D. } & \text { DH/sd } & \text { Prob } \\ \text { EL454_2 } & 60 & 9 & 0.724 & 0.807 & 0.051 & -1.609 & 0.068 \\ \text { EL454_5 } & 60 & 9 & 0.64 & 0.809 & 0.05 & -3.373 & 0.016 \\ \text { EL454_6 } & 60 & 6 & 0.447 & 0.699 & 0.086 & -2.913 & 0.017 \\ \text { EL454_21 } & 60 & 7 & 0.821 & 0.744 & 0.069 & 1.118 & 0.072 \\ \text { EL454_25 } & 60 & 8 & 0.577 & 0.781 & 0.058 & -3.529 & 0.007 \\ \text { EL454_52 } & 60 & 12 & 0.883 & 0.866 & 0.031 & 0.554 & 0.327 \\ \text { EL454_70 } & 58 & 17 & 0.929 & 0.918 & 0.017 & 0.63 & 0.292 \\ \text { EL454_54 } & 56 & 13 & 0.91 & 0.879 & 0.028 & 1.097 & 0.099 \\ \text { EL454_67 } & 50 & 3 & 0.427 & 0.441 & 0.153 & -0.092 & 0.386 \\ \text { EL454_71 } & 48 & 3 & 0.23 & 0.443 & 0.153 & -1.389 & 0.138 \\ \text { EL454_9 } & 52 & 13 & 0.907 & 0.883 & 0.03 & 0.788 & 0.19 \\ \text { EL454_9 } & 52 & 13 & 0.907 & 0.883 & 0.03 & 0.788 & 0.19\end{array}$


Table S12: BOTTLENECK summary statistics for E. southwardae sites Regab, Wormhole and Baboon. T.P.M: Two Phase Model (Wilcoxon test, 1000 replicates). N: sample size, ko: observed number of alleles, He: Hardy-Weinberg heterozygosity, Heq: expected heterozygosity measured, S.D: standard deviation of mutation drift equilibrium distribution of heterozygosity; Prob: probability of obtaining the measured He in a sample from an equilibrium population (Piry et al., 1999).

\section{REGAB}

Under the T.P.M.

\begin{tabular}{|c|c|c|c|c|c|c|c|}
\hline locus & $\mathrm{n}$ & ko & $\mathrm{He}$ & Heq & S.D. & $\mathrm{DH} / \mathrm{sd}$ & Prob \\
\hline ES454_8 & 54 & 6 & 0.556 & 0.7 & 0.085 & -1.696 & 0.064 \\
\hline ES454_10 & 54 & 13 & 0.878 & 0.882 & 0.028 & -0.171 & 0.346 \\
\hline ES454_13 & 52 & 7 & 0.403 & 0.753 & 0.067 & -5.226 & 0.001 \\
\hline ES454_25 & 52 & 16 & 0.924 & 0.91 & 0.031 & 0.443 & 0.337 \\
\hline ES454_28 & 54 & 8 & 0.773 & 0.785 & 0.06 & -0.202 & 0.359 \\
\hline ES454_31 & 52 & 11 & 0.873 & 0.855 & 0.037 & 0.469 & 0.382 \\
\hline ES454_32 & 54 & 5 & 0.273 & 0.638 & 0.103 & -3.558 & 0.006 \\
\hline ES454_34 & 54 & 7 & 0.738 & 0.75 & 0.073 & -0.166 & 0.338 \\
\hline ES454_44 & 52 & 6 & 0.67 & 0.7 & 0.086 & -0.345 & 0.293 \\
\hline ES454_45 & 52 & 11 & 0.467 & 0.855 & 0.037 & -10.564 & 0 \\
\hline ES454_50 & 50 & 9 & 0.82 & 0.816 & 0.05 & 0.069 & 0.445 \\
\hline ES454_57 & 54 & 10 & 0.853 & 0.834 & 0.044 & 0.431 & 0.386 \\
\hline ES454_60 & 54 & 7 & 0.419 & 0.745 & 0.073 & -4.488 & 0 \\
\hline ES454_64 & 52 & 4 & 0.337 & 0.556 & 0.129 & -1.699 & 0.082 \\
\hline ES454_71 & 50 & 15 & 0.847 & 0.908 & 0.019 & -3.242 & 0.01 \\
\hline ES454_95 & 54 & 5 & 0.708 & 0.64 & 0.111 & 0.608 & 0.303 \\
\hline
\end{tabular}


WORMHOLE

\begin{tabular}{|c|c|c|c|c|c|c|c|}
\hline locus & $\mathrm{n}$ & ko & $\mathrm{He}$ & Heq & S.D. & $\mathrm{DH} / \mathrm{sd}$ & Prob \\
\hline ES454_8 & 50 & 6 & 0.601 & 0.704 & 0.086 & -1.209 & 0.108 \\
\hline ES454_10 & 48 & 11 & 0.846 & 0.86 & 0.033 & -0.44 & 0.262 \\
\hline ES454_13 & 50 & 8 & 0.42 & 0.784 & 0.063 & -5.815 & 0.001 \\
\hline ES454_25 & 50 & 18 & 0.939 & 0.93 & 0.015 & 0.614 & 0.331 \\
\hline ES454_28 & 48 & 7 & 0.791 & 0.756 & 0.067 & 0.521 & 0.364 \\
\hline ES454_31 & 50 & 19 & 0.918 & 0.936 & 0.013 & -1.347 & 0.099 \\
\hline ES454_32 & 50 & 4 & 0.406 & 0.559 & 0.13 & -1.177 & 0.14 \\
\hline ES454_34 & 48 & 6 & 0.72 & 0.71 & 0.082 & 0.116 & 0.464 \\
\hline ES454_44 & 50 & 5 & 0.628 & 0.65 & 0.102 & -0.215 & 0.329 \\
\hline ES454_45 & 50 & 10 & 0.452 & 0.838 & 0.043 & -8.976 & 0 \\
\hline ES454_50 & 42 & 11 & 0.859 & 0.867 & 0.032 & -0.233 & 0.324 \\
\hline ES454_57 & 50 & 9 & 0.841 & 0.817 & 0.046 & 0.511 & 0.371 \\
\hline ES454_60 & 50 & 9 & 0.624 & 0.816 & 0.048 & -3.988 & 0.005 \\
\hline ES454_64 & 44 & 6 & 0.645 & 0.716 & 0.08 & -0.894 & 0.16 \\
\hline ES454_71 & 46 & 16 & 0.902 & 0.919 & 0.019 & -0.837 & 0.148 \\
\hline ES454_95 & 50 & 6 & 0.754 & 0.707 & 0.082 & 0.58 & 0.323 \\
\hline \multicolumn{8}{|c|}{ Under the T.P.M. } \\
\hline Locus & $\mathrm{n}$ & ko & $\mathrm{He}$ & Heq & S.D. & $\mathrm{DH} / \mathrm{sd}$ & Prob \\
\hline ES454_8 & 54 & 6 & 0.606 & 0.705 & 0.086 & -1.146 & 0.128 \\
\hline ES454_10 & 56 & 15 & 0.848 & 0.9 & 0.024 & -2.205 & 0.045 \\
\hline
\end{tabular}




$\begin{array}{lccccccr}\text { ES454_13 } & 54 & 9 & 0.422 & 0.812 & 0.049 & -8.013 & 0 \\ \text { ES454_25 } & 54 & 15 & 0.902 & 0.904 & 0.021 & -0.11 & 0.379 \\ \text { ES454_28 } & 56 & 7 & 0.778 & 0.75 & 0.066 & 0.418 & 0.408 \\ \text { ES454_31 } & 54 & 14 & 0.901 & 0.895 & 0.024 & 0.274 & 0.487 \\ \text { ES454_32 } & 56 & 2 & 0.036 & 0.241 & 0.166 & -1.236 & 0.164 \\ \text { ES454_34 } & 56 & 5 & 0.732 & 0.636 & 0.105 & 0.919 & 0.157 \\ \text { ES454_44 } & 54 & 5 & 0.643 & 0.642 & 0.11 & 0.012 & 0.414 \\ \text { ES454_45 } & 54 & 14 & 0.66 & 0.893 & 0.028 & -8.48 & 0.002 \\ \text { ES454_50 } & 56 & 7 & 0.686 & 0.745 & 0.073 & -0.818 & 0.181 \\ \text { ES454_57 } & 54 & 13 & 0.88 & 0.883 & 0.028 & -0.099 & 0.376 \\ \text { ES454_60 } & 54 & 6 & 0.441 & 0.701 & 0.089 & -2.922 & 0.02 \\ \text { ES454_64 } & 56 & 6 & 0.443 & 0.702 & 0.087 & -2.997 & 0.015 \\ \text { ES454_71 } & 48 & 16 & 0.861 & 0.916 & 0.019 & -2.985 & 0.01 \\ \text { ES454_95 } & 56 & 7 & 0.784 & 0.746 & 0.072 & 0.521 & 0.356\end{array}$


Table S13: Summary of null allele frequencies for 28 loci across three described species of Escarpia. $N_{F}$ refers to the null allele frequency and $S E$ refers to the standard error. The Individual Inbreeding Model (IIM) was implemented in INEst v1.0 (Chybicki and Burczyk, 2009)

\begin{tabular}{|c|c|c|c|}
\hline \multirow{2}{*}{$\begin{array}{c}\text { Escarpia taxa } \\
\text { (9 loci) }\end{array}$} & \multicolumn{3}{|c|}{ Summary Statistics for null alleles (means across all loci) } \\
\hline & $N_{A}$ & $N_{F}$ & $S E$ \\
\hline E. spicata & 8 & 0.123 & 0.067 \\
\hline E. laminata & 13 & 0.086 & 0.022 \\
\hline E. southwardae & 12 & 0.058 & 0.028 \\
\hline Escarpia laminata & \multicolumn{3}{|c|}{ Summary Statistics for null alleles (means across all loci) } \\
\hline (11 loci) & $N_{A}$ & $N_{F}$ & $S E$ \\
\hline AC601 & 7.3 & 0.153 & 0.082 \\
\hline AC818 & 5.1 & 0.179 & 0.103 \\
\hline WR269 & 5.7 & 0.203 & 0.111 \\
\hline GC852 & 6.7 & 0.132 & 0.076 \\
\hline AT340 & 6.6 & 0.093 & 0.059 \\
\hline MC294 & 6.4 & 0.173 & 0.101 \\
\hline DC673 & 10.8 & 0.151 & 0.041 \\
\hline WFE & 9.7 & 0.117 & 0.046 \\
\hline Escarpia southwardae & \multicolumn{3}{|c|}{ Summary Statistics for null alleles (means across all loci) } \\
\hline (16 loci) & $N_{A}$ & $N_{F}$ & $S E$ \\
\hline Regab & 8.7 & 0.085 & 0.016 \\
\hline Wormhole & 9.4 & 0.076 & 0.017 \\
\hline Baboon & 9.2 & 0.100 & 0.016 \\
\hline
\end{tabular}


From Cowart et al. 2012 (Table 2): Characteristics of 28 microsatellite loci developed for Escarpia laminata (EL) and Escarpia southwardae (ES)

\begin{tabular}{|c|c|c|c|c|c|c|c|}
\hline Locus & Primers $\left(5^{\prime}-3^{\prime}\right)$ & Repeat Motif & Size Range (bp) & $T_{m}\left({ }^{\circ} \mathrm{C}\right)$ & $N_{A} N_{A}^{3}$ & $H_{o} H_{e}$ & $F_{I S} F_{I S}{ }^{3}$ \\
\hline \multirow[t]{2}{*}{$\overline{\text { EL454_2* }}$} & F: GAGACACCGTACGAATGACAGA & $(\text { TGTGCGCG) })_{19}$ & $135-297$ & 56 & 12 & 0.670 & $0.037 * *$ \\
\hline & R: ACTGGAACTATGGCACGGAC & & & & 31 & 0.720 & 0.031 \\
\hline \multirow[t]{2}{*}{ EL454_5* } & F: TGCATGTATACGTGGAGTGAGA & $(\text { TACATGCA })_{18}$ & $204-288$ & 53 & 15 & 0.751 & 0.007 \\
\hline & R: CCCTGCATTCATAATTGCTT & & & & 30 & 0.750 & 0.018 \\
\hline \multirow[t]{2}{*}{ EL454_6 } & F: TGTGCTTCTCAAACCACC & $(\mathrm{CCACCAT})_{20}$ & $209-254$ & 53 & 8 & 0.388 & 0.085 \\
\hline & R: CAAAAGGCTTTCTCGTCCAC & & & & & 0.415 & \\
\hline \multirow[t]{2}{*}{ EL454_9* } & F: TTATGTTCCCGTTGAAAGCC & $(\mathrm{CACCACA})_{13}$ & $83-185$ & 54 & 19 & 0.682 & $0.314 * *$ \\
\hline & R: GTGGGCGCTATGTCGTATTT & & & & 35 & 0.914 & 0.284 \\
\hline \multirow[t]{2}{*}{ EL454_21* } & F: CTCAGCAGGAGGGTCAGTTC & $(\text { GGAGGC })_{16}$ & $115-176$ & 57 & 9 & 0.753 & $0.070 * *$ \\
\hline & R: AACACACTGCTCTCTCGCAA & & & & 19 & 0.809 & 0.108 \\
\hline \multirow[t]{2}{*}{ EL454_25* } & F: GTGCACTGTTGCATTATGGG & $(\mathrm{AGGGT})_{16}$ & $153-213$ & 52 & 12 & 0.650 & -0.021 \\
\hline & R: CCATACATTCCATACCTTCG & & & & 12 & 0.608 & -0.016 \\
\hline \multirow[t]{2}{*}{ EL454_52* } & F: CGATGATGCCAACTAAATAGGG & $(\text { TGTGTGGC })_{17}$ & $179-313$ & 53 & 16 & 0.794 & 0.069 \\
\hline & R: GACGACATTTAAGACAGGCG & & & & 34 & 0.888 & 0.072 \\
\hline \multirow[t]{2}{*}{ EL454_54 } & F: CGCCCTAAGCACTGTATTCC & $(\mathrm{CACACG})_{14}$ & $139-223$ & 56 & 20 & 0.739 & 0.151 \\
\hline & R: TATAGACGCCAGGTGGAACG & & & & & 0.894 & \\
\hline \multirow[t]{2}{*}{ EL454_64* } & F: AACACCAAAACTGTGTCCTCG & $(\mathrm{CATA})_{24}$ & $185-261$ & 55 & --- & 0.750 & --- \\
\hline & R: ATGCGTGGAATGAAGGAGAC & & & & 20 & 0.835 & 0.039 \\
\hline \multirow[t]{2}{*}{ EL454_67 } & F: TGCAGCAGTTTCACGAACTC & $(\mathrm{TAT})_{15}$ & $92-125$ & 57 & 4 & 0.323 & -0.143 \\
\hline & R: ACGCTTCGTAGCACTGACCT & & & & & 0.286 & \\
\hline \multirow[t]{2}{*}{ EL454_70* } & F: GTGCCGACACTTGAGCACTA & $(\mathrm{TGC})_{16}$ & $100-185$ & 57 & 26 & 0.874 & 0.035 \\
\hline & R: AGGCTAACCATGCAGTCACA & & & & 33 & 0.886 & 0.054 \\
\hline \multirow[t]{2}{*}{ EL454_71* } & F: AATGCCAGATGTTTTCCCAA & $(\mathrm{GTT})_{19}$ & $115-199$ & 54 & 4 & 0.150 & 0.518 \\
\hline & R: TGCAATGGCACACCTGTTAC & & & & 8 & 0.397 & 0.254 \\
\hline \multirow[t]{2}{*}{ ES454_8 } & F: CACTGGGAAAACGGTGAGTT & $(\text { CATCACTA })_{23}$ & $125-198$ & 56 & 9 & 0.530 & 0.096 \\
\hline & R: CGCCTAGCTCTTTCTGAGGTT & & & & & 0.589 & \\
\hline \multirow[t]{2}{*}{ ES454_10 } & F: AAGAACACGGACACGGACAC & $(\mathrm{CACACGCA})_{16}$ & $112-192$ & 54 & 18 & 0.851 & 0.011 \\
\hline & R: CGTCATCATCCTCACATTG & & & & & 0.857 & \\
\hline \multirow[t]{2}{*}{ ES454_13 } & F: ATTCACCCACGCATTCTCTC & $(\mathrm{ACACACGC})_{21}$ & $136-208$ & 56 & 10 & 0.423 & -0.020 \\
\hline & R: GAGTGGGTGAGTGCACGAG & & & & & 0.415 & \\
\hline \multirow[t]{2}{*}{ ES454_25 } & F: GTGGCGTCAGATCCTCAGA & $(\mathrm{GCACAC})_{13}$ & $109-193$ & 56 & 21 & 0.910 & 0.012 \\
\hline & R: CAATGGCAGTACTTCGGGAT & & & & & 0.922 & \\
\hline
\end{tabular}




\begin{tabular}{|c|c|c|c|c|c|c|c|}
\hline ES454_28 & $\begin{array}{l}\text { F: ATGAATGGACTCATCCACGC } \\
\text { R: CATGTTTTACCCTCTTATTACGTTT }\end{array}$ & $(\text { GTGCAT })_{24}$ & $114-162$ & 53 & 11 & $\begin{array}{l}0.785 \\
0.780\end{array}$ & -0.006 \\
\hline \multirow[t]{2}{*}{ ES454_31 } & F: AATGAATTTCCСТCCCAAGG & $(\mathrm{ACACGC})_{28}$ & $131-207$ & 53 & 22 & 0.794 & 0.116 \\
\hline & R: TTCGATTGATGTCATGTCCG & & & & & 0.900 & \\
\hline \multirow[t]{2}{*}{ ES454_32 } & F: GCGTGAGATTCCACCAGAAT & $(\mathrm{CACACG})_{14}$ & $108-168$ & 55 & 5 & 0.164 & $0.302 * *$ \\
\hline & R: CTCACGTGATGTATCGTCCG & & & & & 0.240 & \\
\hline \multirow[t]{2}{*}{ ES454_34 } & F: TATCTGTCTGCCTTCCTGCC & $(\mathrm{CACGCA})_{23}$ & $109-133$ & 55 & 7 & 0.761 & -0.040 \\
\hline & R: GACAACCGTGGCTTTTGAAT & & & & & 0.729 & \\
\hline \multirow[t]{2}{*}{ ES454_44 } & F: GCCCATTTGTTTATCGTGCT & $(\text { TGATGG })_{13}$ & $72-126$ & 52 & 7 & 0.692 & -0.071 \\
\hline & R: CGGGTCTACATAAAAGCTTG & & & & & 0.646 & \\
\hline \multirow[t]{2}{*}{ ES454_45 } & F: GGGATGATAACAAGAAACGC & $(\mathrm{CAGAGG})_{13}$ & $140-251$ & 53 & 23 & 0.230 & $0.569 * *$ \\
\hline & R: TGTCTGTCTGTACGTCTGTTTG & & & & & 0.532 & \\
\hline \multirow[t]{2}{*}{ ES454_50 } & F: ACTGCACAAGATACGATGCG & $(\mathrm{GCGAT})_{20}$ & $95-325$ & 55 & 13 & 0.785 & 0.130 \\
\hline & R: CTAAGTCTCGTTTTCGGCGT & & & & & 0.788 & \\
\hline \multirow[t]{2}{*}{ ES454_57 } & F: ACGCACTCACTCACGCAG & $(\mathrm{GTGC})_{28}$ & $118-202$ & 56 & 16 & 0.836 & 0.027 \\
\hline & R: GGGTTGGTGTTTGTGGAA & & & & & 0.858 & \\
\hline \multirow[t]{2}{*}{ ES454_60 } & F: TCCTCGTCAGACAATCCAAA & $(\mathrm{TCCA})_{34}$ & $152-200$ & 56 & 10 & 0.536 & -0.083 \\
\hline & R: CCCAACCACGGGACACTAC & & & & & 0.494 & \\
\hline \multirow[t]{2}{*}{ ES454_64 } & F: CACACAAATGACATCCTAGCG & $(\mathrm{AGAC})_{20}$ & $104-137$ & 55 & 8 & 0.473 & 0.010 \\
\hline & R: GCGCATGTGTGCGTGTAT & & & & & 0.475 & \\
\hline \multirow[t]{2}{*}{ ES454_71 } & F: AATGGGTACACAATACCGCC & $(\text { TGTC })_{25}$ & $127-199$ & 56 & 24 & 0.837 & 0.042 \\
\hline & R: AGGCAGATGAAACGGAGTGT & & & & & 0.871 & \\
\hline \multirow[t]{2}{*}{ ES454_95 } & F: CGCGTTCCTCACTATCACAA & $(\mathrm{TTA})_{19}$ & $124-148$ & 55 & 8 & 0.739 & 0.016 \\
\hline & R: CTGGTGAGCAGATGAAAGCA & & & & & 0.749 & \\
\hline
\end{tabular}

*Loci amplified across three Escarpia species, $\mathrm{T}_{m}=$ Annealing temperature, $N_{A}=$ number of observed alleles $N_{A}{ }^{3}=$ number of observed alleles across three species, $H_{o}=$ observed heterozygosity, $H_{e}=$ expected heterozygosity $F_{I S}{ }^{3}=\mathrm{F}_{\text {IS }}$ values across three species

$* *$ Significant deviation from HWE after FDR correction $=0.01$ 